\title{
CLUSTER THINNING EFFECTS ON METHOXYPYRAZINE, RESVERATROL AND BERRY CHEMISTRY IN VITIS VINIFERA CV. CABERNET SAUVIGNON
}

\author{
A Thesis \\ Presented to the Faculty of \\ California Polytechnic State University, \\ San Luis Obispo
}

\author{
In Partial Fulfillment \\ of the Requirements for the Degree \\ Master of Science in Agriculture, with Specializations in Crop Science
}

By

Thomas Jerome Fertel

June 2011 


\section{Copyright (C) 2011}

Thomas Jerome Fertel

ALL RIGHTS RESERVED 


\section{COMMITTEE MEMBERSHIP}

TITLE:

CLUSTER THINNING EFFECTS ON

METHOXYPYRAZINE, RESVERATROL AND BERRY

CHEMISTRY IN VITIS VINIFERA CV. CABERNET

SAUVIGNON

AUTHOR: $\quad$ Thomas Jerome Fertel

DATE SUBMITTED: June 2011

COMMITTEE CHAIR: $\quad$ W. Keith Patterson, Ph.D.

COMMITTEE MEMBER: J. Wyatt Brown, Ph.D.

COMMITTEE MEMBER: $\quad$ Brian Hampson, Ph.D. 


\begin{abstract}
CLUSTER THINNING EFFECTS ON METHOXYPYRAZINE, RESVERATROL AND BERRY CHEMISTRY IN VITIS VINIFERA CV. CABERNET SAUVIGNON
\end{abstract}

\author{
Thomas Jerome Fertel
}

\begin{abstract}
Cabernet sauvignon is the most widely planted red wine grape in California and is valued in the hundreds of millions of dollars. Cabernet sauvignon grapes, when severely vigorous or overcropped, can contain vegetal aromas and flavors when harvested. 3alkyl-methoxypyrazines are the volatile compounds responsible for this effect and can lower the perceived quality of the wine. Resveratrol is a phytoalexin that has many medical and health benefits and can be found in red wines. An experiment was conducted in Paso Robles, CA to assess the effects of five yield levels, manipulated through cluster thinning, on methoxypyrazine and resveratrol concentrations. Berry weights and chemistry were also measured, in the form of ${ }^{\circ} \mathrm{Brix}, \mathrm{pH}$, and TA. In 2009 and 2010, no significant statistical differences were found in methoxypyrazines in the harvested grapes. In 2009, resveratrol concentrations were below the detection limits in the wine produced. In 2010, berry weight and chemistry measurements were not significantly different, except for grapes from lightly- and greatly-thinned vines which varied in $\mathrm{pH}$ at harvest. The 2009 wines were subjected to discrimination and preference testing by trained tasters. No significant difference was found in the discrimination test and no difference was found using the Friedman and Kramer's Rank test for the preference test. Only a very slight difference was found between the wines made from unthinned and greatly-thinned vines according to Tukey's Multiple Comparison Test. The findings of this thesis suggest that cluster thinning does not affect methoxypyrazine and resveratrol concentrations or sensory analysis in Cabernet sauvignon grown on the east side of Paso Roble, CA.
\end{abstract}

Keywords: Vitis vinifera, Cabernet sauvignon, cluster thinning, methoxypyrazines, resveratrol. 


\section{ACKNOWLEDGMENTS}

I would like to thank the many people at California Polytechnic State University in San Luis Obispo, CA (Cal Poly) who helped me with this undertaking: Dr. Keith Patterson, my mentor, who was instrumental in my arrival at Cal Poly to begin with, and from whom I learned all I know about viticulture; Dr. Brown who gave me guidance and allowed me to use his lab; and Dr. Hampson who helped me with ideas on interpreting data.

This study would not be possible without the help of Mr. Raymond Derby, and Tiffinee and Steve Vierra, who provided the vineyard site and helped handle harvesting and winemaking. I would also like to thank the Horticulture and Crop Science Department which provided McOmie funds to support this research.

I would like to thank Mr. Gordon Burns, Steve Price, and Benoit Largeteau at ETS Laboratories, who gave me a discounted rate on berry and wine analysis.

I would like to thank my mother, father, step-father Danny, and brothers Rien and Daniel for their full support.

I would like to thank other Cal Poly faculty, whom helped me during my time here:

Dr. David Headrick, Dr. Michael Costello, Dr. Gerry Ritchie, Dr. Bruce Zoecklein, Mark Welch and Jim Shumate.

I would like to thank all my friends back in Louisiana and new California friends Jeremy Leffert, Melissa Burns, Jon Martin, Annie Geratowski, Linnea Norton, Ethan Heller, Todd Ricard, Chris and Adrienne Ferrara, Craig Macmillan, Leola Dublin, Brian Henriott, and Liz Palmieri.

I would like to thank Peachy Canyon Winery and Frank Family Vineyards who gave me my first jobs in the wine industry.

Finally, I would like to dedicated this body of work to my grandmother, Ruth U. Fertel. 


\section{TABLE OF CONTENTS}

Page

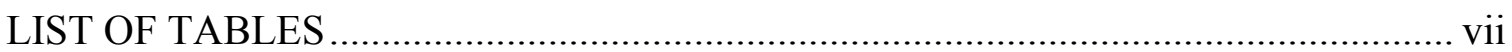

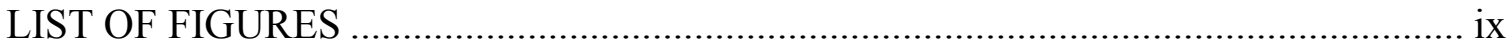

\section{CHAPTERS}

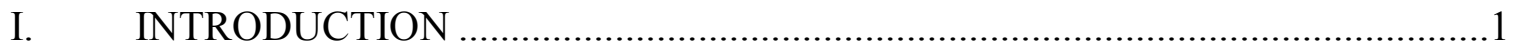

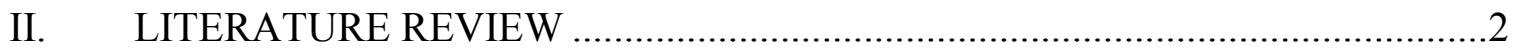

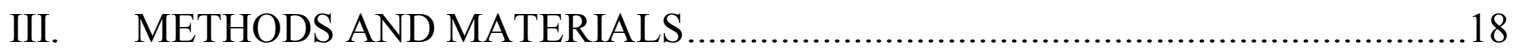

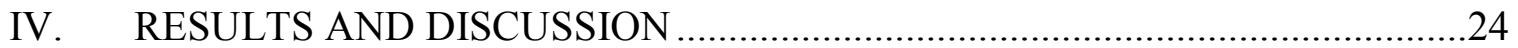

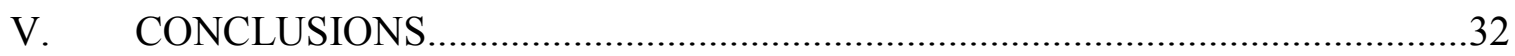

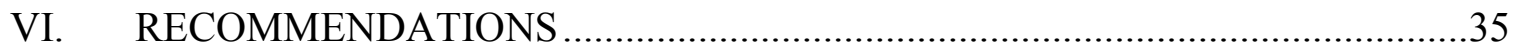

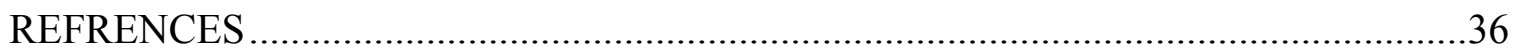

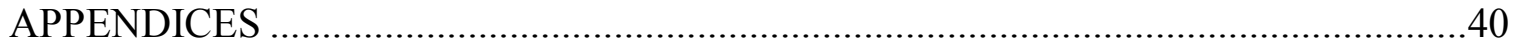

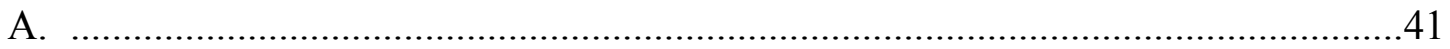

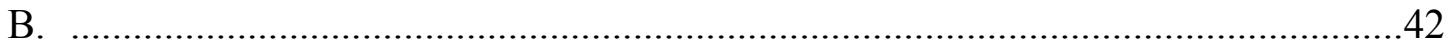

C. .

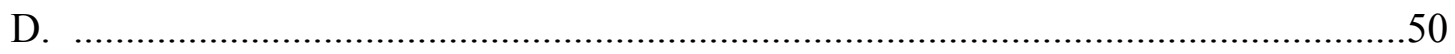

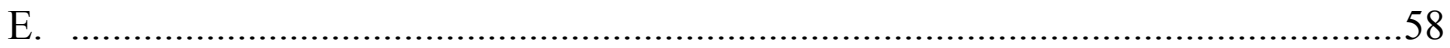




\section{LIST OF TABLES}

Table

Page

Table 1. Sensory threshold values of 3-alkyl-2-methoxypyrazines perceived by a human nose in distilled water or red wine. 9

Table 2. Influence of cluster thinning on average cluster and berry weights, berries per cluster, clusters per vine and estimated yield of Cabernet sauvignon, 2009 and 2010.

Table 3. Influence of cluster thinning on berry chemistry of Cabernet sauvignon, 2009 and 2010.

Table 4. Influence of cluster thinning on total resveratrol in the 2009 Cabernet sauvignon wines. .30

Table 5. Degree-days accumulated in Paso Robles, CA, with a lower limit of $50^{\circ} \mathrm{F}$....41

Table 6. Precipitation in Paso Robles, CA from December $1^{\text {st }}$ of the previous year to June $1^{\text {st }}$.

Table 7. Randomly selected treatment order, from east to west, of Cabernet sauvignon.

Table 8. 2009 berries per cluster from Cabernet sauvignon bunches.

Table 9. 2009 total and average cluster and berry weights of Cabernet sauvignon.

Table 10. 2009 soluble solids, $\mathrm{pH}$, and titratable acidity of Cabernet sauvignon.

Table 11. 2009 methoxypyrazine and resveratrol data of Cabernet sauvignon.

Table 12. Preference rankings of the five 2009 Cabernet sauvignon wines. .44

Table 13. 2010 berries per cluster counts at lag phase of Cabernet sauvignon. .45

Table 14. 2010 cluster counts per treatment. .45 
Table 15. 2010 cluster weights of Cabernet sauvignon.

Table 16. September 2, 2010 berry chemistry data of Cabernet sauvignon.

Table 17. September 21, 2010 berry chemistry data of Cabernet sauvignon.

Table 18. November 2, 2010 berry chemistry data of Cabernet sauvignon..

Table 19. 2010 methoxypyrazine data of Cabernet sauvignon, in $\mathrm{ng} / \mathrm{kg}$ total methoxypyrazines. 


\section{LIST OF FIGURES}

Figure

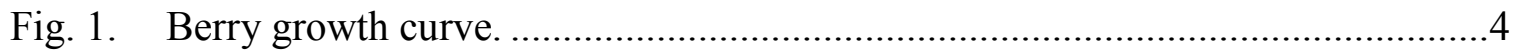

Fig. 2. Chemical formulas for the 3-alkyl-2-methoxypyrazines................................

Fig. 3. Methoxypyrazine accumulation and degradation in grapes over time. .............11

Fig. 4. Chemical formulas for the different resveratrol isomers. ................................16

Fig. 5. Derby Wine Estates site location. ............................................................19

Fig. 6. Sample collection in Block 14 of Derby Wine Estates vineyard. ......................33

Fig. 7. Down the row look at Block 14 of Derby Wine Estates vineyard.....................33

Fig. 8. Field refractometer used to measure soluble solids. ....................................58

Fig. 9. Edge of Block 14 of Derby Wine Estates vineyard. .......................................58

Fig. 10. Close up of the canopy in Block 14 of Derby Wine Estates vineyard...............59

Fig. 11. Lag phase in Block 14 of Derby Wine Estates vineyard. ...............................59 


\section{CHAPTER I \\ INTRODUCTION}

Grapevines have been cultivated since before the early Egyptians, and vineyards were started approximately 6,000 years ago (Keller, 2010; This et al., 2006). Vine cultivation and wine making techniques were passed on to the Greeks and Romans around 200 - 400 A.D. (Bamforth, 2008; Insel, 2008; Kennedy et al., 2006). Wine travelled the world, and grapes were cultivated wherever land seemed suitable. European producers began to make superior age-worthy vintages and looked to grow grapes in the new world in the eighteenth century. Today, every continent but Antarctica cultivates grapes and produces wine. Worldwide, the wine industry employs over a million people and is valued at over 33 billion dollars per year (Bamforth, 2008; Insel, 2008; Kennedy et al., 2006). Studies are performed every year on vineyard management practices and their effects on grape and wine quality, due to the expansive nature of the wine industry.

Hundreds of tons of California wine grapes are culled every year to decrease vine crop weight in an attempt to concentrate berry flavors and aromas. However, the relationship between vineyard crop weight and grape quality is not fully understood and depends on the vineyard and the grower. The objective of this research was to determine how cluster thinning treatments affect methoxypyrazine and resveratrol content in Cabernet sauvignon grown in Paso Robles, CA. 


\section{CHAPTER II}

\section{LITERATURE REVIEW}

\section{Classification and History}

Grapevines are in the family Vitaceae of the kingdom Plantea. The vine is a dicotyledonous angiosperm, meaning it contains two embryonic leaves and is a flowering plant (Galet, 2000). Vitis is the most important of the 19 grapevine genera, and includes approximately 60 species all of which originated in the Northern Hemisphere. The Vitis genus is a perennial shrub that produces shoots with leaves, inflorescences, and tendrils. Vitis grows in the wild in temperate climates and has a longitudinal growing limit. Most Vitis species are found either in the Americas or Asia; however, $V$. vinifera L. originated in Eastern Europe and is the only species grown around the world for wine production (This et al., 2006). $V$. vinifera produces pentamerous flowers, has $2 \mathrm{n}=38$ chromosomes, and may be polyploidy in nature (Mullins et al., 1992). V. vinifera is used globally for table grape and raisin consumption, winemaking, distillation, and grape-seed oil production (Galet, 2000).

$V$. vinifera is believed to have originated about 65 million years ago and was cultivated approximately $7,400-8,000$ years ago along with olives, figs and dates (Keller, 2010). The earliest domesticated grape seeds to be discovered were found in Georgia and eastern Turkey and are approximately 7,400 - 8,000 years old. Domesticated grapes were used for winemaking, fresh fruit and raisin production, and precede Sumer, the earliest civilization, by about 2,000 years. Wild grape seed remains dating back 3,500 years have been discovered in parts of Western Europe, including 
France, and suggest that grape cultivation played an important role in early societies (This et al., 2006).

$V$. vinifera was cultivated by all Mediterranean civilizations, including the Egyptians, Greeks, Romans, and Carthaginians (This et al., 2006). The Catholic Church used grape vines to spread their religion to Northern Europe and Islam used table grapes as a way to spread their faith to Northern Africa and the Middle East. $V$. vinifera was brought to the New World in the $16^{\text {th }}$ century and to South Africa, Australia, and New Zealand in the $19^{\text {th }}$ century.

\section{Berry Growth}

Berry development follows a double sigmoid curve and is divided into three stages (Fig. 1). Stage I begins after fruit set and lasts about 40 - 60 days (Mullins et al., 1992). The berry undergoes a rapid increase in size and mass through cell division of the seed and pericarp, but not the embryo. In stage I, titratable acid (TA) and other organic compounds accumulate in the small, hard green berries. Stage II, known as the lag phase, has little to no berry growth and lasts $7-14$ days, depending on the maturing characteristics of the cultivar. At this point, berry photosynthesis and respiration decrease, and chlorophyll levels decline. TA reaches a maximum and the berry remains hard and green. The shoots are the major nutrient sink in the vine before ripening, and this switches to the berry at veraison (Mullins et al., 1992). Veraison marks the beginning of Stage III and is noted by the coloring, softening, and ripening of the berry (Wrinkler et al, 1974). During veraison, the berry begins to increase in size via cell 


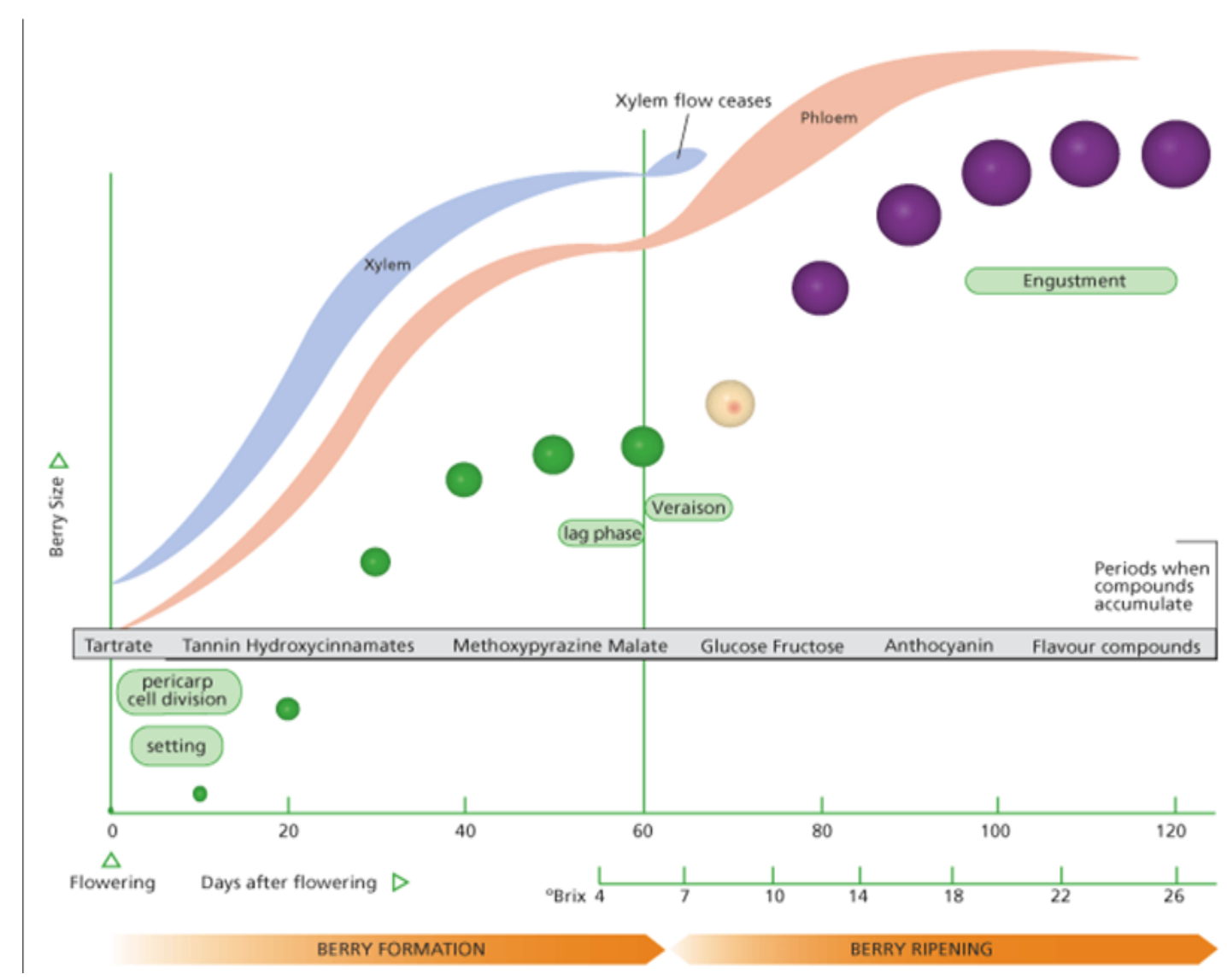

Fig. 1. Berry growth curve (adapted from Kennedy, 2002).

enlargement, anthocyanins in red varieties first appear giving the berry color, and TA decreases, due to dilution as the berry increases in size, as sugars begin to accumulate. Stage III lasts from 35 - 55 days until harvest, depending on the characteristics of the cultivar, the vineyard site, heat accumulation, pests and vineyard management.

The chemical composition of the berry is undergoing a constant change near harvest time, and the grower must decide when to harvest, based on desirable berry qualities (Winkler et al., 1974). Vineyard management techniques can shorten or lengthen ripening time and can greatly alter berry composition and quality (Mullins et al., 1992). 


\section{Fruit Quality and Crop Yield Relationships}

Grape quality is the deciding factor in wine quality and is primarily dictated by the “terroir” (Bravdo, 2004; Prezler et al., 2010). Terroir is an all-encompassing term giving a definitive setting to the vine. Soil, climate, variety, vineyard geology, slope, and crop load are some of the aspects pertaining to terroir. As wine quality is directly related to its commercial market value, its relationship with crop yield is extensively studied and debated. Crop load is one of the most important aspects of grape and wine quality.

\section{Overcropping}

Overcropping occurs when vine clusters do not evenly and fully ripen and is a result of an imbalance in vine physiology (Edson et al., 1995). Overcropping leads to delayed maturity, and reduced acidity, color, and quality (Ough and Nagaoka, 1984). In extreme cases, the vine's future can be negatively affected due to a decrease in growth, yield, wine quality, and a lower winter hardiness (Ferree et al., 2003; Mullins et al., 1992). Since large crop loads are inversely related to shoot vigor, leaf size, and leaf area, it is important for the vine to balance the carbohydrates produced from photosynthesis for optimal growth and berry quality (Edson et al., 1995). Overcropping can be adjusted in the vineyard by different techniques including: trellising, pruning, irrigation scheduling, and shoot and cluster thinning (Bravdo et al., 1985).

\section{Cluster Thinning}

Cluster thinning (CT) is a viticultural tool used to correct overcropping or improve fruit composition (Reynolds et al., 2007). CT is used to find a balance between shoot 
growth and berry development. The timing of $\mathrm{CT}$ affects yield components such as berries per cluster, berry weight, and berry size. CT before berry set has been shown to increase berry weight (Weaver and Pool, 1973), increase berries per cluster (Smithyman et al., 1998), and increase berry size (Reynolds et al., 2007). For table grapes, larger berries are desired, and CT is advised around berry set (Mazza et al, 1999; Prajitna et al., 2007). For wine grapes, smaller berries are preferred, to increase the skin to pulp ratio during fermentation, which can improve wine aromas and flavors. Therefore, the best time to cluster thin for wine grapes is before veraison. CT has been shown to affect other factors such as yield, soluble solids, $\mathrm{pH}$, titratable acidity (TA), anthocyanin content and composition, and sensory qualities.

\section{Crop Load and Berry Size}

In a majority of crop thinning studies, crop load decreased due to the actual cutting of the fruit before it has reached full maturity (Reynolds et al., 2007). Thus, the total yield was lower for the thinned vines compared to the control. Reduced crop load is considered an artifact of crop thinning so researchers concentrate on other factors such as cluster weight, berry size, and berry composition.

Cluster thinning during stage I will increase berry size as more energy is focused into cell division for fewer berries (Keller, 2010; Smart and Robinson, 1991). Table grape growers use this strategy to increase the size of their grapes to make them more marketable. Cluster thinning at, or after, lag phase will have no effect on berry size as cell elongation is occurring. Wine grape growers prefer this to maintain a high pulp to juice ratio while hastening ripening. 


\section{${ }^{\circ}$ Brix, pH, and Titratable Acidity}

High crop loads have shown to delay fruit maturity through slower sugar accumulation (Edson et al., 1995). Soluble solids, measured as ${ }^{\circ}$ Brix, increase with CT severity, due to the vine having less fruit to ripen and this occurs independently of when the CT is performed, after berry set or at lag phase (Guidoni et al., 2002; Jackson and Lombard, 1993; Keller et al., 2005; Reynolds et al., 2007). This allows for a more rapid accumulation of soluble solids into the berries from the leaves and shoots.

CT has shown to increase $\mathrm{pH}$ levels in berry and must composition, which can have a negative effect on wine quality; however, it is unclear as to how $\mathrm{CT}$ affects $\mathrm{pH}$ (Edson et al., 1995; Morris et al., 1987; Reynolds et al., 2007; Smithyman et al., 1998). CT has also shown to increase potassium levels in Cabernet sauvignon and Carignane wines which increases $\mathrm{pH}$ levels (Hepner and Bravdo, 1985). Titratable acidity is not significantly changed by cluster thinning in Thompson seedless (Weaver and Pool, 1973), Seyval blanc (Edson et al., 1995; Smithyman et al., 1998), and Chardonnay Musqué grapes (Reynolds et al., 2007; Smithyman et al., 1998; Weaver and Pool, 1973).

\section{Methoxypyrazines}

The 3-alkyl-2-methoxypyrazine (MP) chemical class contains volatile compounds responsible for the herbaceous and vegetal aromas and flavors typically found in bell peppers, asparagus, and some wines (Allen et al., 1991; Belancic and Agosin, 2007; Bogart and Bisson, 2006; Lacey et al., 1991; Noble et al., 1995; Scheiner et al., 2009). The chemical 3-isobutyl-2-methoxypyrazine (IBMP) was first discovered in green bell peppers by Buttery et al. in 1969 and since has been found in ripened fruit of various $V$. 
vinifera cultivars. All cultivars studied have measurable MP levels pre-veraison, but some varieties, such as Cabernet sauvignon, Sauvignon blanc, Merlot, and Carmenere may have excessive concentrations at harvest.

IBMP has shown to be the primary MP compound in grapes and has a distinct green bell pepper characteristic; however, three other less studied compounds, 3-isopropyl-2methoxypyrazine (IPMP), 3-sec-butyl-2-methoxypyrazine (SBMP), and 3-ethyl-2methoxypyrazine (EMP), have been identified in wines and provide a range of vegetal flavors and aromas at various thresholds (Fig. 2 and Table 1). Little research has been done on the perception of these other MP compounds (Preston et al., 2008; Sala et al., 2004).

A positive correlation has been shown between increased IBMP concentration and perceived green bell pepper intensity in wine (Preston et al., 2008). Winemakers have found limited success in removing MPs from juice and wine via micro-oxygenation, activated charcoal and extended oak aging because desirable wine components are diminished (Scheiner et al., 2009). Viticulturalists and winemakers have shown an interest in understanding how methoxypyrazine concentrations may be manipulated in the vineyard. 


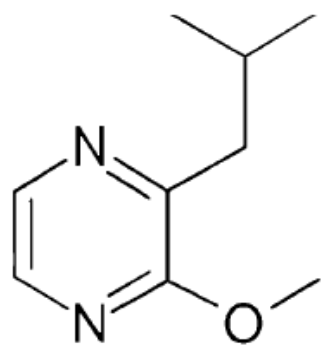

3-isobutyl-2-methoxypyrazine<smiles>COc1nccnc1C(C)C</smiles>

3-isopropyl-2-methoxypyrazine<smiles>CC[C](C)c1nccnc1OC</smiles>

3-sec-butyl-2-methoxypyrazine<smiles>CCc1nccnc1OC</smiles>

3-ethyl-2-methoxypyrazine

Fig. 2. Chemical formulas for the 3-alkyl-2-methoxypyrazines (adapted from Hartmann et al., 2002).

Table 1. Sensory threshold values of 3-alkyl-2-methoxypyrazines perceived by a human nose in distilled water or red wine (Godelmann et al., 2008; Sala et al., 2004).

\section{3-alkyl-2-methoxypyrazine}

3-isobutyl-2-methoxypyrazine (IBMP)

3-sec-butyl-2-methoxypyrazine (SBMP)

3-isopropyl-2-methoxypyrazine (IPMP)

3-ethyl-2methoxypyrazine (EMP)
Threshold values (ng/L)

$1-2(10-15$ in red wine $)$

$1-2$

$1-2$ (2 in red wine)

425 
MP formation begins at berry set, but the majority accumulates between 30 to 50 days post-bloom and begins to decline at veraison, due to berry enlargement and dilution (Fig. 3). MP concentrations continue to decline throughout maturation due to tissue age, heat, and light (Ryona et al., 2008; Scheiner et al., 2009). Initially, IBMP is located primarily in the stems, with lower concentrations in the skins and seeds, with the berry

flesh containing very little. At harvest, MP concentrations are usually only $5 \%$ to $10 \%$ of the maximum concentration observed pre-veraison.

Winemaking processes such as maceration in reds, cold settling in whites, pressing, and blending can affect MP concentration (de Boubée et al., 2002; Sala et al., 2004). However, the primary factor is the composition of the grapes, as the majority of the MPs are extracted within the first 24 hours of maceration. Therefore, viticulturalists and winemakers are aware of some of the effects variety, climate, maturity, water and soil, shading, vigor and crop load have on the accumulation and the degradation of MPs in the vineyard (Scheiner et al., 2009).

\section{Maturity}

MP concentrations decline during berry maturation; therefore, early harvested grapes have high MP levels (Sala et al., 2004). Diseases and pests that slow berry maturation, such as grape leafroll virus, have higher MP levels then disease and pest-free vines. Grapes that have been grown in cooler regions have shown to have an increased MP content when compared to warmer regions. Data does not indicate if excessive hang time will decrease MP levels. One study suggests that MP concentration plateaus before 


\section{Methoxypyrazine Concentration Over Berry Development}

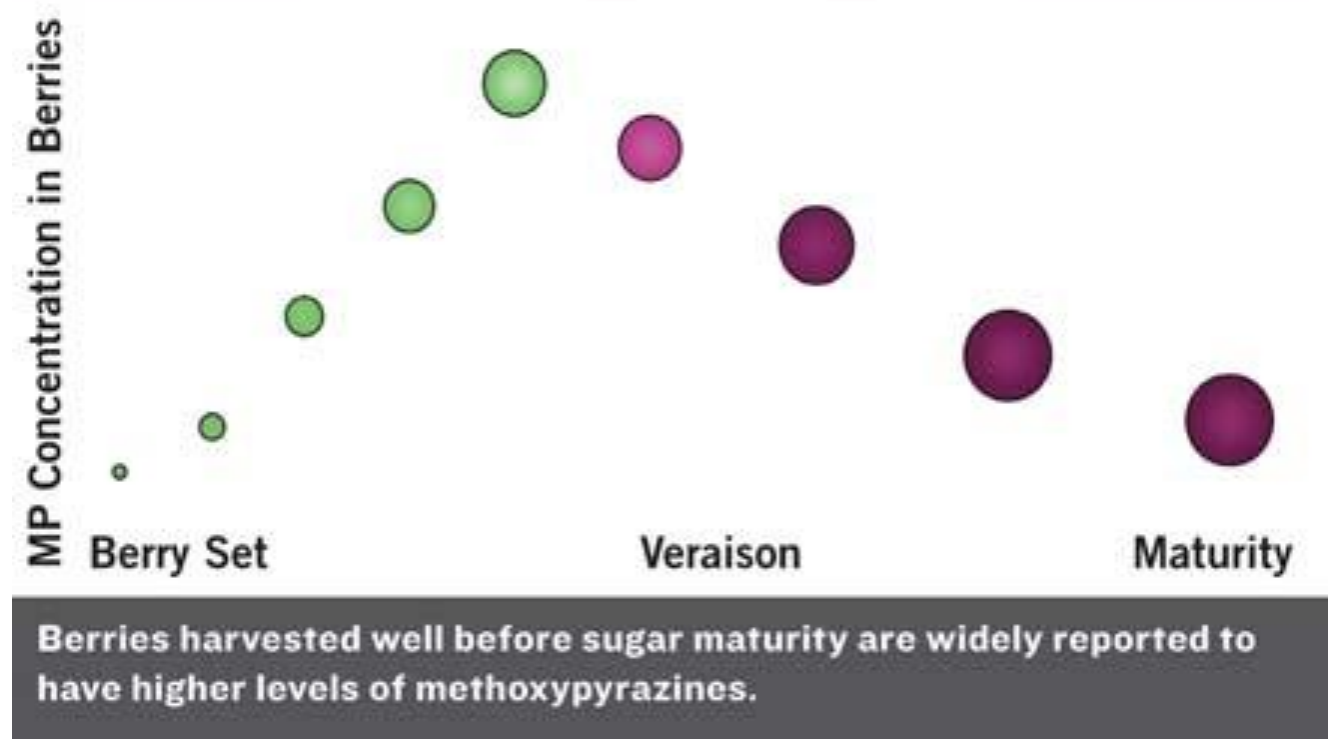

Fig. 3. Methoxypyrazine accumulation and degradation in grapes over time (adapted from Scheiner et al., 2009).

sugars stop accumulating, but data are sparse (Belancic and Agosin, 2007; Scheiner et al., 2009). Winemakers have tasted for MPs in grapes to determine ripeness (Hashizume and Samuta, 1999).

\section{Shading}

MP levels may be manipulated by applying light and increasing berry temperature. Viticulturalists open the canopy pre-veraison to decrease MP accumulation and postveraison to increase MP degradation. Ennahli, as cited in Scheiner et al. (2009), reported that the greatest decrease in MPs occurred when the clusters were exposed shortly after fruit set, rather than veraison. Thus, viticulturalists should open the canopy after berry 
set if the vineyard has MP problems (Hashizume and Samuta, 1999; Scheiner et al., 2009).

Exposing the berry clusters to light has shown to decrease MP levels at an increasing rate (Scheiner et al., 2009). Allen (1996) showed that heavily shaded clusters had 3 times the MPs than exposed clusters at harvest and veraison. Sala et al. (2004) demonstrated that Cabernet sauvignon clusters protected with sackcloth produced wine with more MPs than those exposed to sunlight. Ryona (2008) showed that well-exposed clusters had lower MP accumulation pre-veraison, while the percentage of MP degradation postveraison was similar in shaded and exposed clusters. Most data shows that early cluster exposure, after fruit set, inhibits MP accumulation (Scheiner et al., 2009). Furthermore, photo degradation of MPs has been shown in the laboratory as florescent light decreased MP levels in wine by up to $28 \%$ (Heymann et al., 1986).

\section{Vigor and crop load}

Rapid vine growth and high planting density have been shown to increase MP concentrations (Scheiner et al., 2009). High vigor can result in shading, and studies show that vigorous vines produce fruit with high MP levels pre-harvest, irrespective of cluster light exposure. Increased planting density increased the number of shoots per linear foot of trellis which increased canopy shade and therefore MPs (Sala et al., 2005). Lakso, as cited in Scheiner et al. (2009), found that shoots that grew longer and faster pre-veraison produced clusters with more MPs at their pre-veraison peak. Scheiner suggested that crop load, measured as a yield to pruning weight ratio, was more directly related to MPs than vigor alone (Scheiner et al., 2009). 


\section{Water and soil}

Water availability and soil type have been shown to affect MP concentrations due to changes in vigor (Sala et al., 2005). Irrigated vines had significantly higher IBMP concentrations compared to non-irrigated controls and this was attributed to increased vigor and canopy shading. The water-holding capacity and nutrient status of soils has been shown to impact vigor, canopy size and wine flavor (Smart and Robinson, 1991). Vines grown in a shallow, sandy soil poor in nutrients and low water-holding capacity were of low vigor, had an open canopy, and produced fruity wines. Vines grown in a deep, clay soil rich in nutrients and with a high water-holding capacity were vigorous, had dense canopies, and produced vegetally-flavored wines (Scheiner et al., 2009). The larger canopies and shading led to higher MP concentrations in the fruit (Noble et al., 1995).

\section{Temperature and Humidity}

Growing degree-days and MP concentrations are reported to be inversely correlated, indicating the effect of both temperature and sunlight on MPs (Scheiner et al., 2009). Humidity during berry development phase I increases MP concentrations (de Boubée et al., 2000). Sauvignon blanc grown in cool climates had more MPs than grapes grown in hotter climates (Allen and Lacey, 1993). However, the impact of temperature and humidity on MP accumulation and degradation, independent of other viticultural factors, is still not clearly understood (Scheiner et al., 2009). 


\section{Control of MPs in the vineyard}

Methoxypyrazine concentrations are managed by controlling vine vigor and limiting pre-veraison cluster shading, beginning with proper vineyard planning and planting, which includes rootstock and scion selection to match oil and climate, and providing proper drainage, vine spacing, training systems, and nutrient management (Scheiner et al., 2009; Smart and Robinson, 1991). Balanced pruning, based on the previous year's growth, is the best technique to manipulate vine size, but will take more man hours than mechanical pruning. When pruning vigorous vines, more nodes are left on the vines impacting vigor and shoot density. However, increased shoot densities may lead to shading, and therefore a new trellis system may be required. If retrofitting the trellis is not an option, basal leaf removal early in berry development is recommended to decrease cluster shading.

Wines made from older Cabernet sauvignon vines had more fruity aromas and flavors compared to wines made from younger Cabernet sauvignon vines which had more bell pepper and vegetal aromas and flavors (Heymann and Noble, 1987). Replanting a vineyard could therefore give rise to potential MP problems that were not seen in the previous vineyard.

A strong correlation between malic acid and MP degradation shows the two processes occurring simultaneously during ripening, irrespective of soil type, variety, and climate (de Boubée et al., 2000). The pathways are likely not related, but allow winemakers to use MPs as a marker for ripening. Currently, some winemakers choose to harvest Cabernet sauvignon based on the absence of the green bell pepper aroma and flavor in the juice, indicating ripeness (Hashizume and Samuta, 1999). 


\section{Ideal concentrations}

Methoxypyrazines can add complexity or typicity to some Sauvignon blanc wines, however MPs are regularly perceived to negatively impact red wine quality, except in high quality Bordeaux wines (Sala et al., 2004). The MP threshold in water is $1-2 \mathrm{ng} / \mathrm{L}$ and the ideal range in Sauvignon blanc is $8-20 \mathrm{ng} / \mathrm{L}$, depending on wine style. The ideal range found in high quality Boudreaux wines is $7-15 \mathrm{ng} / \mathrm{L}$ (Allen, 1995). The winemaker's style will ultimately direct the aroma and flavor profile of the wine, from vegetal to fruit forward, as long as vineyard practices are properly coordinated and understood. Optimizing vine balance and light into the canopy are two major factors in lowering MP accumulation, and maximizing fruit quality (Scheiner et al., 2009).

\section{Resveratrol}

The "French Paradox" questioned the country's cuisine and lifestyle pertaining to overall health (Sala et al., 2004; Udenigwe et al., 2008; Woraratphoka et al., 2007). The French have a very low risk of developing cardiovascular disease, despite having a diet rich in saturated fat. Scientists began to look at red wine as a key to the paradox. Wine was found to be rich in polyphenolic and antioxidant compounds. Resveratrol, in particular, was found to have several beneficial health qualities, and is found in red wines.

Resveratrol is a phytoalexin compound in the stilbene phenolic class. This nonflavonoid has different forms, such as trans-, cis-, and piceid (Fig. 4). The trans- isomer has the greatest health benefits, although the other isomers are physiologically important. Resveratrol has been shown to lower the risk of heart disease, prevent platelet 

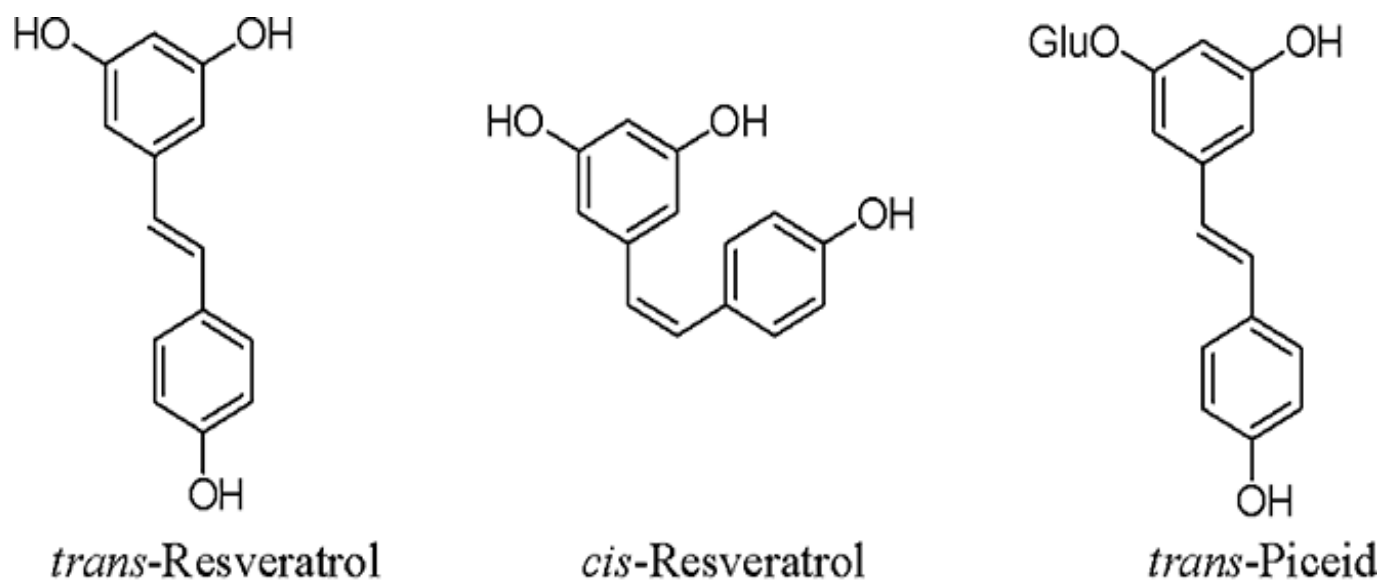

Fig. 4. Chemical formulas for the different resveratrol isomers (adapted from Udenigwe et al., 2008).

accumulation, act as an anti-inflammatory, and prevent low-density lipoprotein cholesterol oxidation. It also displays chemotherapeutic properties by preventing the initiation, promotion, and growth of tumors (Romero-Pérez et al., 1999; Udenigwe et al., 2008; Woraratphoka et al., 2007). Resveratrol is very sensitive to air- and photooxidation and should be measured under nitrogen gas and protected from light during testing (Pezet et al., 1994).

The mechanism for resveratrol formation in grapes is not understood, but is dependent on variety, geology, environment, soil pathogens, and vineyard and winemaking practices (Prajitna et al., 2007; Udenigwe et al., 2008). Red wines have more resveratrol and antioxidants than white wines, due to extended maceration on the skins (Romero-Pérez et al., 1999). Resveratrol is usually found in greater concentration in the grapes from organic vines, highly stressed vines, and vines subjected to high humidity and disease pressures. Studies have shown that low crop levels and cluster thinning can increase total resveratrol and phenolic concentrations although how crop levels influence resveratrol is not known (Prajitna et al., 2007). 


\section{Summary}

Cluster thinning vines during lag phase (II) of berry growth may decrease yields and acid levels yet increase soluble solids and resveratrol concentration (Reynolds et al., 2007). MPs may or may not decrease with cluster thinning depending on vigor and canopy shading (Scheiner et al., 2009). Cluster thinning may not always be economical for the grower or winemaker if fruit quality does not significantly increase (Preszler et al., 2010). 


\section{CHAPTER III}

\section{METHOD AND MATERIALS}

\section{Vineyard Site and Growing Conditions}

A field experiment was conducted in 2009 and 2010 on Vitis vinifera cv. Cabernet sauvignon clone 15 grapevines grafted to $110 \mathrm{R}$ rootstock in block 14 of Derby Wine Estates Vineyard (Fig. 5) in Paso Robles, California (35³9’36.10” N, 120³5’43.40” W). The vineyard was planted in 1997 using 726 vines/acre in a 10' (between row) x 6' (inrow) configuration with vines orientated east-west. Vines were trained on a bilateral cordon, with some unilateral cordons spaced throughout the vineyard, approximately thirty-two inches above the ground. Vines were trellised on a vertical shoot positioning system, averaging fifteen spurs per vine, and were pruned to two buds per spur. The vines used in the experiment were planted in a Diablo soil which consists of $3-4$ feet of high shrink-swell clay. The soil has a calcareous parent material and a high free-lime concentration.

The following vineyard practices were completed in both experimental years. The vineyard was irrigated at a rate of ten acre inches per year. Vines were sprayed with a $10 \%$ zinc sulfate solution at the rate of two pounds per acre and $5 \%$ iron lignosulfonate solution at the rate of one gallon per acre. Vines were fertilized with thirty pounds actual nitrogen per acre per year and forty pounds of potash $\left(\mathrm{K}_{2} \mathrm{O}\right)$ per acre per year. 


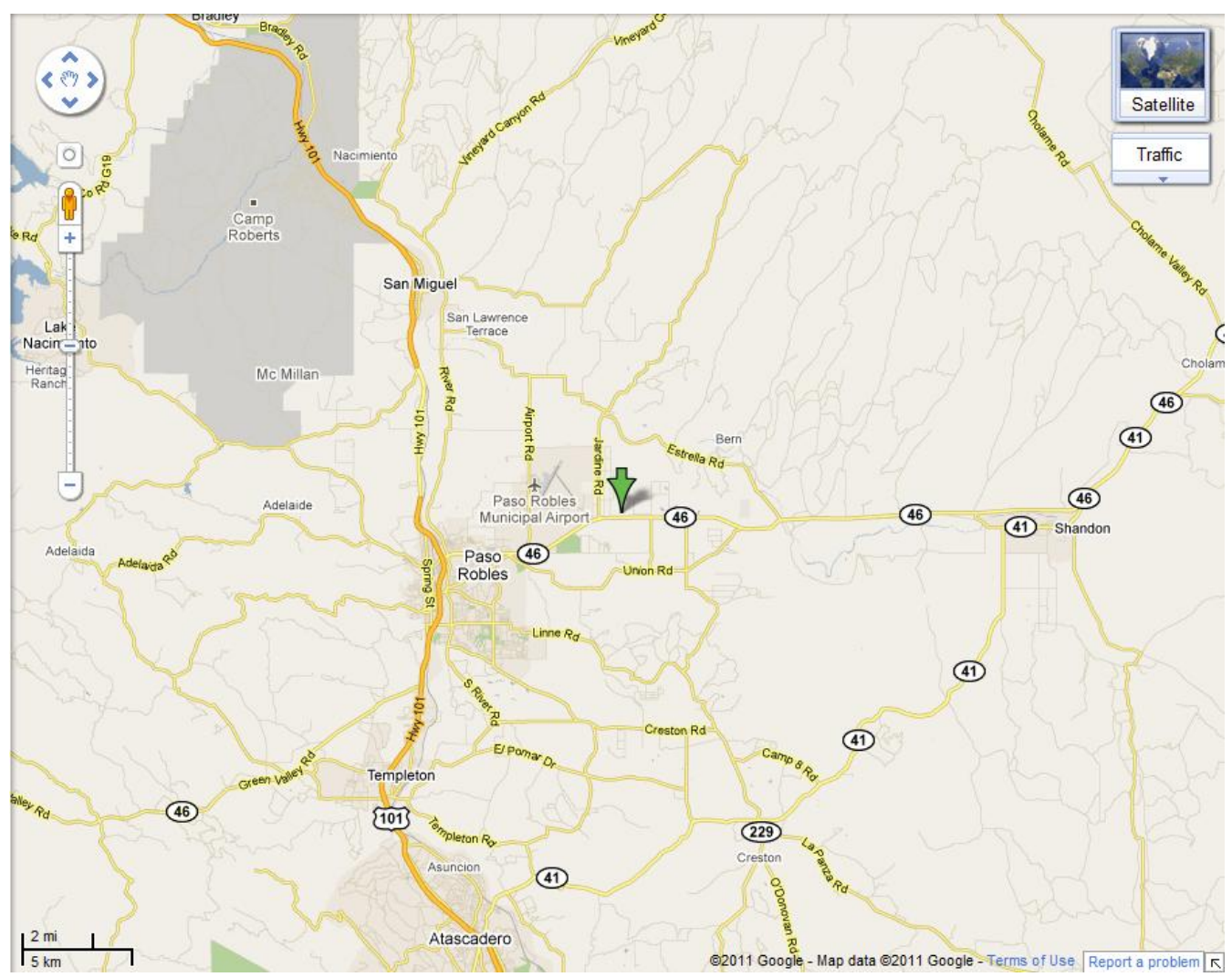

Fig. 5. Derby Wine Estates site location.

\section{Experimental Design}

Two hundred vines were used in this experiment, consisting of fifty-vine plots within each of four contiguous rows. Plots were divided into 5, 10-vine sub-plots and randomly assigned a treatment. Treatments consisted of the following:

- Treatment 1: Unthinned control (C).

- Treatment 2: Lightly-thinned (LT): Two clusters per shoot with wings attached.

- Treatment 3: Moderately-thinned (MT): Two clusters per shoot with wings removed.

- Treatment 4: Greatly-thinned (GT): One cluster per shoot with wings attached.

- Treatment 5: Severely-thinned (ST): One cluster per shoot with wings removed. 
Cluster thinning was performed during lag phase (Phase II), as determined by the presence of seed coats within the developing berries, to prevent yield compensation. The vineyard manager provided weekly ${ }^{\circ}$ Brix levels which were used to determine sampling dates. Berry set was the primary factor used to determine whether to remove the first or second cluster on each shoot, for the greatly- and severely-thinned treatments.

\section{Berry Sampling: 2009}

Cluster thinning was performed on the mornings of July $22-25$, 2009. Berries per cluster were determined for randomly selected bunches. Clusters per vine were determined for 3 contiguous vines within each treatment replicate and used to estimate yields. Cluster samples were taken on August 31, September 21, and the harvest date of October 26, and measured for weight, soluble solids, $\mathrm{pH}$, titratable acidity (TA), total MPs and total resveratrol. Due to financial constraints, bunches from each set of treatment replications were pooled and statistical analysis was therefore not possible. With additional funding in 2010, the sampling technique was corrected to include replicates.

For the first two sampling dates, MPs and resveratrol concentration were determined from expressed juice by ETS Laboratory (St. Helena, CA). At harvest, samples of 250 berries were sent to ETS Labs for MP analysis. Resveratrol was not measured at harvest because no resveratrol had been detected in the juice provided from grapes harvested August 31 or September 21, and total resveratrol is only accurately detected in finished wine (Steve Price, 2009, personal communication). MPs were measured using gas 
chromatography coupled with a mass spectrometer (GC-MS) and total resveratrol was measured using high performance liquid chromatography (HPLC).

\section{Winemaking: 2009}

Clusters were harvested by thinning treatment into half-ton micro bins and taken to Paso Robles Wine Services (Paso Robles, CA), just a few miles from the Derby Wine Estates Vineyard. Clusters were de-stemmed and dropped onto a vibrating sorting table to remove material other than grape (MOG). Whole berries were dropped into half-ton macro bins for fermentation. Berries came into the winery at $\sim 12.8^{\circ} \mathrm{C}\left(55^{\circ} \mathrm{F}\right)$ and were inoculated the next day using yeast D - 21 (Saccharomyes cerevisia). The must was punched down twice a day by hand. The must was pressed once alcoholic fermentation was complete and then malolactic fermentation (MLF) was allowed to begin. The five wines were kept separate throughout the winemaking and bottling process. No oak was added to the wines during maturation and MLF was completed before bottling.

\section{Berry Sampling and Harvest: 2010}

Cluster thinning was performed during berry lag phase on the mornings of July 27 30, 2010. Berries per cluster and clusters per vine were counted as before. Cluster samples were taken on September 2, September 29, and the harvest date of November 2, 2010, and the clusters from the treatment replicates were kept separate. Clusters were weighed as before. Estimated harvest yield was calculated by multiplying the average clusters per vine by average cluster weight by vines per acre. Clusters were frozen at $80^{\circ} \mathrm{C}$ and later de-stemmed and refrozen. Freezing grapes has been shown to have no 
effect on sensory preference but can lower acidity (Spayd et al., 1987). Frozen berry samples, consisting of 200 berries, were sent to ETS Laboratory and analyzed, as before, for MPs. A total of 55 samples were analyzed for total MPs. Grapes from row 55 of the study were not analyzed as these vines were machine harvested before the grapes could be sampled on November 2. Soluble solids were measured as before. TA and pH were determined for the expressed juice. Wine was not made in 2010 due to mechanical harvesting of the entire vineyard, not allowing for resveratrol and wine sensory analysis.

\section{Sensory Analysis}

Sensory analysis was performed on 2009 wines using a trained panel at Cal Poly. The wines were assessed using triangle and preference tests. The triangle test, the most powerful discrimination test, consisted of two pours of wine made from grapes harvested from unthinned vines compared to one pour of wine made from grapes harvested from the severely-thinned vines. Tasters were to determine which two pours were the same wine. The preference test utilized the five wines produced from the grapes harvested from the various treatment plots. The wines were presented to the tasters and each wine was ranked using a hedonic scale of 1 through 5, with 1 indicating the wine most preferred. For this test, the tasters had no knowledge of the history of the grapes used to make the wines. The tasters were trained in sensory analysis for two months before taking the tests. 


\section{Statistical Analysis}

Data was analyzed using the one-way analysis of variance unstacked (ANOVA)

procedure of the Minitab software program (Minitab ${ }^{\circledR}$ Inc., State College, PA). Means were separated using Tukey’s Multiple Comparison Test. 


\section{CHAPTER IV}

\section{RESULTS AND DISCUSSION}

\section{Samples for Analysis}

Juice samples were sent to ETS Labs (St. Helena, CA) after cluster collection on the first and second sampling dates of 2009. Steve Price of ETS Labs corrected this, in late September, 2009. He stated that berries were needed for methoxypyrazine (MP) analysis and finished wine was needed for resveratrol analysis, as resveratrol is bound to sugars and is best detected after fermentation. Berries were sent to ETS Labs for MP analysis after the third sampling date and finished wine samples were sent for resveratrol analysis in January, 2011.

\section{Weight Measurements: 2009}

The results indicate that there were fewer clusters on the severely-thinned vines than on the unthinned vines, which was expected (Table 2). Early in ripening, the clusters from lightly-thinned vines were much heavier than clusters from vines subjected to the other thinning treatments; however at harvest all clusters were similar in weight. This is unexpected as wingless clusters would be expected to weigh less than winged clusters. However, berry compensation can result in more assimilates being imported into fewer berries, creating larger berries in severely-thinned vines. Overall, cluster weights were 
Table 2. Influence of cluster thinning on average cluster and berry weights, berries per cluster, clusters per vine and estimated yield of Cabernet sauvignon, 2009 and 2010.

\begin{tabular}{|c|c|c|c|c|c|c|c|c|c|}
\hline \multirow[b]{2}{*}{ Treatment } & \multicolumn{2}{|c|}{ Sample Date $1^{\mathrm{Z}}$} & \multicolumn{2}{|c|}{ Sample Date $2^{\mathrm{y}}$} & \multicolumn{2}{|c|}{ Sample Date $3^{\mathrm{x}}$} & \multirow[b]{2}{*}{$\mathrm{ABC}^{\mathrm{u}}$} & \multirow[b]{2}{*}{$\mathrm{AVC}^{\mathrm{t}}$} & \multirow[b]{2}{*}{$\mathrm{ETA}^{\mathrm{s}}$} \\
\hline & $\mathrm{ACW}^{\mathrm{W}}$ & $\mathrm{ABW}^{\mathrm{V}}$ & ACW & ABW & $\mathrm{ACW}$ & $\mathrm{ABW}$ & & & \\
\hline \multicolumn{10}{|l|}{$2009^{r}$} \\
\hline Unthinned & 120 & 1.11 & 110 & 1.09 & 90 & 0.90 & 104 & 52 & 3.91 \\
\hline Lightly-Thinned & 230 & 2.17 & 130 & 1.25 & 100 & 0.96 & 104 & 45 & 3.60 \\
\hline Moderately-Thinned & 160 & 1.57 & 120 & 1.20 & 90 & 0.85 & 104 & 45 & 3.17 \\
\hline Greatly-Thinned & 120 & 1.16 & 120 & 1.11 & 90 & 0.90 & 104 & 35 & 2.63 \\
\hline Severely-Thinned & 100 & 0.91 & 120 & 1.11 & 100 & 0.96 & 104 & 35 & 2.80 \\
\hline \multicolumn{10}{|l|}{2010} \\
\hline Unthinned & 150 & 0.94 & 160 & 1.06 & 150 & 1.00 & 155 & $49 \mathrm{a}$ & 5.92 \\
\hline Lightly-Thinned & 150 & 1.04 & 150 & 1.04 & 150 & 1.01 & 148 & $44 \mathrm{ab}$ & 5.27 \\
\hline Moderately-Thinned & 140 & 1.04 & 130 & 0.94 & 150 & 1.14 & 140 & $42 \mathrm{ab}$ & 5.03 \\
\hline Greatly-Thinned & 150 & 1.07 & 150 & 1.10 & 150 & 1.10 & 131 & $37 \mathrm{ab}$ & 4.44 \\
\hline Severely-Thinned & 140 & 1.07 & 150 & 1.18 & 150 & 1.18 & 127 & $33 \mathrm{~b}$ & 3.95 \\
\hline Signif. $^{\mathrm{q}}$ & $\mathrm{ns}$ & ns & ns & ns & ns & $\mathrm{ns}$ & ns & $*$ & ns \\
\hline
\end{tabular}

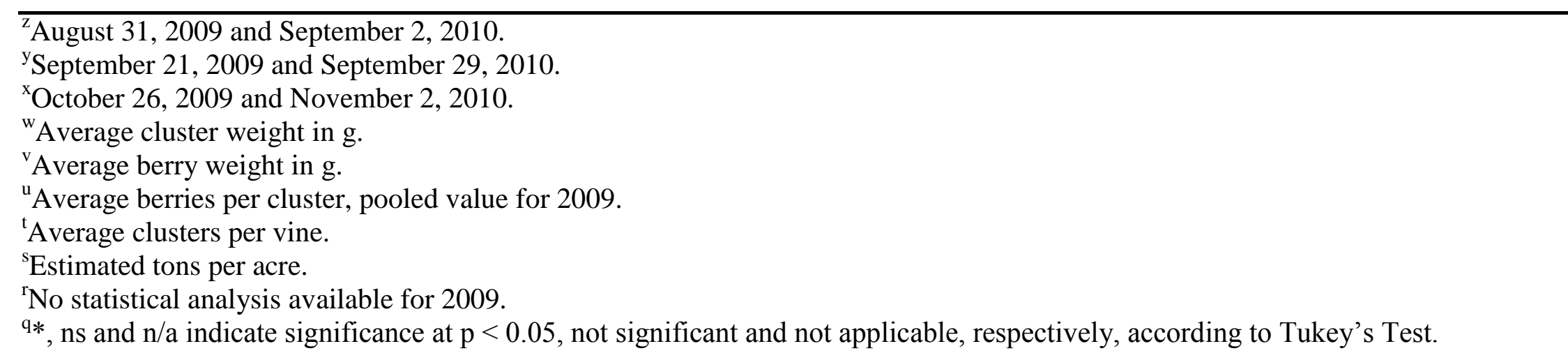


similar for all of the vines, though there were slight differences in berry weight.

\section{Weight Measurements: 2010}

There were fewer clusters on the severely-thinned vines than on the unthinned vines, which was expected (Table 2). Overall, the severely-thinned vines tended to produce fewer tons per acre than the unthinned vines. Berries from severely-thinned vines were heavier than the berries from unthinned vines. This could be due to vine imbalance in which the vine exports more assimilates into fewer berries allowing for greater cell enlargement. Cluster weights were similar between all of the vines, on the three sampling dates. Cluster and berry weights were higher in 2010 than 2009 and this was attributed to the higher level of rainfall in spring 2010 (Table 2; Appendix A: Table 6). In general, berries per cluster decreased as thinning severity increased which was expected, except for the clusters from moderately-thinned vines, which could be due to vine variation.

\section{Berry Chemistry: 2009}

In general, berries from the severely-thinned vines contained more soluble solids than berries from vines with lighter crop loads (Table 3). This was expected due to berry compensation, and was observed in previous studies (Edson et al., 1995; Reynolds et al., 2007). In general, the fruit from lightly-thinned vines retained more acid than the fruit from vines with other crop loads. However, the general results indicate that the fruit from all of the vines had similar titratable acidities, which was expected and observed 
Table 3. Influence of cluster thinning on berry chemistry of Cabernet sauvignon, 2009 and 2010.

\begin{tabular}{|c|c|c|c|c|c|c|c|c|c|c|c|c|}
\hline \multirow[b]{2}{*}{ Treatment } & \multicolumn{3}{|c|}{ Sample Date $1^{\mathrm{z}}$} & \multicolumn{5}{|c|}{ Sample Date $2^{\mathrm{y}}$} & \multicolumn{4}{|c|}{ Sample Date $3^{\mathrm{x}}$} \\
\hline & $\mathrm{SS}^{\mathrm{W}}$ & $\mathrm{pH}$ & $\mathrm{TA}^{\mathrm{v}}$ & $\mathrm{MP}^{\mathrm{u}}$ & $\mathrm{SS}$ & $\mathrm{pH}$ & $\mathrm{TA}$ & MP & SS & $\mathrm{pH}$ & TA & MP \\
\hline \multicolumn{13}{|l|}{$2009^{t}$} \\
\hline Unthinned & 18.0 & 3.22 & 8.3 & 4.4 & 20.6 & 3.39 & 6.0 & $<3.0$ & 22.6 & 3.63 & 5.4 & $<5.0$ \\
\hline Lightly-Thinned & 18.0 & 3.14 & 8.7 & 4.3 & 20.6 & 3.42 & 5.6 & $<3.0$ & 22.6 & 3.47 & 5.7 & $<5.0$ \\
\hline Moderately-Thinned & 18.1 & 3.14 & 9.4 & 6.2 & 21.2 & 3.45 & 5.9 & $<3.0$ & 21.6 & 3.52 & 9.6 & $<5.0$ \\
\hline Greatly-Thinned & 19.0 & 3.20 & 8.2 & 7.0 & 21.2 & 3.43 & 5.8 & $<3.0$ & 22.4 & 3.54 & 9.2 & $<5.0$ \\
\hline Severely-Thinned & 20.0 & 3.25 & 7.5 & 5.1 & 21.3 & 3.51 & 5.0 & $<3.0$ & 23.0 & 3.65 & 8.5 & $<5.0$ \\
\hline \multicolumn{13}{|l|}{2010} \\
\hline Unthinned & $15.3 \mathrm{ab}$ & $3.30 \mathrm{ab}$ & $8.40 \mathrm{ab}$ & 63.4 & 18.7 & 3.67 & 4.96 & 24.0 & 22.0 & $3.98 \mathrm{ab}$ & 4.08 & 9.8 \\
\hline Lightly-Thinned & $13.5 \mathrm{a}$ & $3.19 \mathrm{a}$ & $9.56 \mathrm{a}$ & 77.8 & 18.0 & 3.68 & 4.65 & 25.9 & 21.8 & $3.80 \mathrm{a}$ & 4.23 & 6.2 \\
\hline Moderately-Thinned & $15.8 \mathrm{ab}$ & $3.27 \mathrm{ab}$ & $8.77 \mathrm{ab}$ & 79.8 & 18.6 & 3.75 & 4.26 & 28.7 & 22.8 & $4.09 \mathrm{ab}$ & 3.73 & 10.6 \\
\hline Greatly-Thinned & $16.5 \mathrm{ab}$ & $3.32 \mathrm{ab}$ & $7.90 \mathrm{ab}$ & 69.1 & 19.3 & 3.84 & 4.53 & 32.4 & 23.1 & $4.07 \mathrm{ab}$ & 3.77 & 9.0 \\
\hline Severely-Thinned & $17.6 \mathrm{~b}$ & $3.39 \mathrm{~b}$ & $7.36 \mathrm{~b}$ & 62.6 & 19.5 & 3.83 & 4.38 & 34.3 & 23.3 & $4.15 \mathrm{~b}$ & 3.57 & 13.5 \\
\hline Signif. & $*$ & $* *$ & $*$ & ns & ns & ns & ns & ns & ns & $*$ & ns & ns \\
\hline
\end{tabular}

${ }^{\mathrm{z}}$ August 31, 2009 and September 2, 2010.

${ }^{\mathrm{y}}$ September 21, 2009 and September 29, 2010.

${ }^{\mathrm{x}}$ October 26, 2009 and November 2, 2010.

${ }^{\mathrm{w}}$ Soluble solids expressed as ${ }^{\circ}$ Brix.

${ }^{\mathrm{v}}$ Titratable acidity as $\mathrm{g} / \mathrm{L}$ total titratable acidity.

${ }^{u}$ Methoxypyrazine concentration as ng/L in 2009 (except Sample Date 3) and ng/kg in 2010 (including Sample Date 3, 2009).

${ }^{t}$ No statistical analysis available for 2009; sample dates 1 and 2 methoxypyrazine concentrations as ng/L total methoxypyrazine.

$\mathrm{s}_{*}, * *$, and ns indicate significance at $\mathrm{p}<0.05,0.01$ and not significant, respectively, according to Tukey's Test. 
in previous studies (Edson et al., 1995; Reynolds et al., 2007; Smithyman et al., 1998). At harvest, the titratable acidity of the grape juice from moderately- and greatly-thinned vines was surprising as it was not expected to be above $9 \mathrm{~g} / \mathrm{L}$. The test was repeated in triplicate and similar results were obtained each time. It is not understand why acids levels were so high in these grapes.

\section{Berry Chemistry: 2010}

The fruit from lightly- and severely-thinned vines harvested at the first sampling date differed in soluble solids, $\mathrm{pH}$, and $\mathrm{TA}$, but not at the second sampling date and only differed in $\mathrm{pH}$ at harvest (Table 3 ). There were no other differences in berry chemistry. In general, the results indicate that the fruit from severely-thinned vines had the greatest soluble solids, highest $\mathrm{pH}$, and lowest TA, suggesting that the fruit was overripe (Edson et al., 1995; Reynolds et al., 2007). Differences in juice $\mathrm{pH}$ at harvest was due to the removal of cluster wings. The lack of differences in berry chemistry from all of the vines was attributed to a cooler growing and ripening season compared to 2009 (Appendix A: Table 5).

\section{Methoxypyrazines: 2009}

Fruit from moderately-, greatly-, and severely-thinned vines retained more methoxypyrazines than the fruit from lightly-thinned and unthinned vines (Table 3). This suggests that more MPs accumulated in the fruit of vines with fewer clusters. By the second sampling date, the MP concentrations of the fruit from all vines were below the detection limit of the GC-MS. Having berries analyzed for the first two sampling dates, 
instead of juice, and keeping the treatment replicates separate would have provided not only more useful data but would have allowed the data to be statistically analyzed.

\section{Methoxypyrazines: 2010}

The MP concentrations of the berries from all of the vines were similar (Table 3). The MP concentration of berries from lightly-thinned vines degraded at a faster rate than in berries from vines subjected to other levels of thinning, and the berries from severelythinned vines degraded the slowest. Leaf pulling has been shown to increase the rate of MP degradation as has increased sunlight on the developing berries (Scheiner et al., 2009; Smart and Robinson, 1991). In this experiment, leaf pulling did not occur, nor was the amount of sunlight hitting the berries measured. Therefore, it not possible to correlate ambient sunlight with the varying rates of MP degradation.

\section{Resveratrol: 2009}

The resveratrol concentrations for the five wines made in 2009 were below the detection limit of the HPLC (Table 4). These low levels of resveratrol could have been due to low disease pressure in 2009 as stressed vines have been shown to produce grapes with higher levels of resveratrol (Prajitna et al., 2007). Resveratrol is also subject to photo- and air-oxidation but the conditions of testing for resveratrol at ETS Labs is not known. 
Table 2. Influence of cluster thinning on total resveratrol in the 2009 Cabernet sauvignon wines.

\begin{tabular}{lcc}
\hline & \multicolumn{2}{c}{ Resveratrol } \\
\cline { 2 - 3 } Treatment & $\mathrm{mg} / \mathrm{L}$ & micromoles/L \\
\hline Unthinned & $<0.1$ & $<0.4$ \\
Lightly-Thinned & $<0.1$ & $<0.4$ \\
Moderately-Thinned & $<0.1$ & $<0.4$ \\
Greatly-Thinned & $<0.1$ & $<0.4$ \\
Severely-Thinned & $<0.1$ & $<0.4$ \\
\hline
\end{tabular}

\section{Wine: 2009}

Wines made from unthinned and severely-thinned vines were judged by 25 trained tasters in a triangle test. Only 12 of the 25 tasters correctly identified the wine made from the severely-thinned vines indicating that the wines were indistinguishable. Cluster thinning therefore had very little effect on wines made from unthinned and severelythinned vines.

The five wines produced from the treatment vines were judged by 24 trained tasters in a preference test (Appendix B, Table 12). The tasters ranked the wines according to preference using a 1 - 5 hedonic scale, with one indicating the most preferred. There were only small differences in wine preference. The Friedman test and Kramer's Rank test indicated no difference among the tasters' for any of the wines, while Tukey's Multiple Comparison Test indicated a very slight difference in preference for wines made from unthinned and greatly-thinned vines $(p<0.05)$. The wine with the highest preference ranking was the wine made from unthinned vines. The wine made from moderately-thinned vines received the second highest ranking, followed by the wine 
made from severely-thinned vines, then lightly-thinned vines, and, lastly, the wine made from greatly-thinned vines. This indicates that cluster thinning had very little effect on wines made from vines with various crop loads. 


\section{CHAPTER V}

\section{CONCLUSIONS}

The fruit harvested from Cabernet sauvignon grapevines with various crop loads in Block 14 of the Derby Wine Estates vineyard did not differ in berry chemistry, methoxypyrazine (MP) or resveratrol concentration. Cluster thinning of the Cabernet sauvignon grapevines did not influence the fruits' MP concentration; however, the MP concentration of the fruit from severely-thinned vines was more than double that of the fruit from lightly-thinned vines. This suggests that cluster thinning may influence grape MP accumulation and degradation rates. For grapevines with fewer clusters, higher MP levels would require either additional cluster hang time or more light into the canopy to degrade MP concentrations below threshold levels.

Methoxypyrazine and resveratrol analysis at a commercial lab was very expensive. If these analyses had been performed at California Polytechnic, it would not only have saved thousands of dollars but the analytical methodologies would have been fully understood allowing for a more precise interpretation of the data.

Although pruning weights and berry exposure to sunlight were not measured, photos indicate excessive shoot growth which could have impeded light penetration into the fruit zone (Fig. 6 and 7). Vineyard managers could potentially save thousands of dollars by not cluster thinning, and still retain the quality of fruit that they desire. However, the findings of this study cannot be extrapolated to other grapevine varieties or to other 


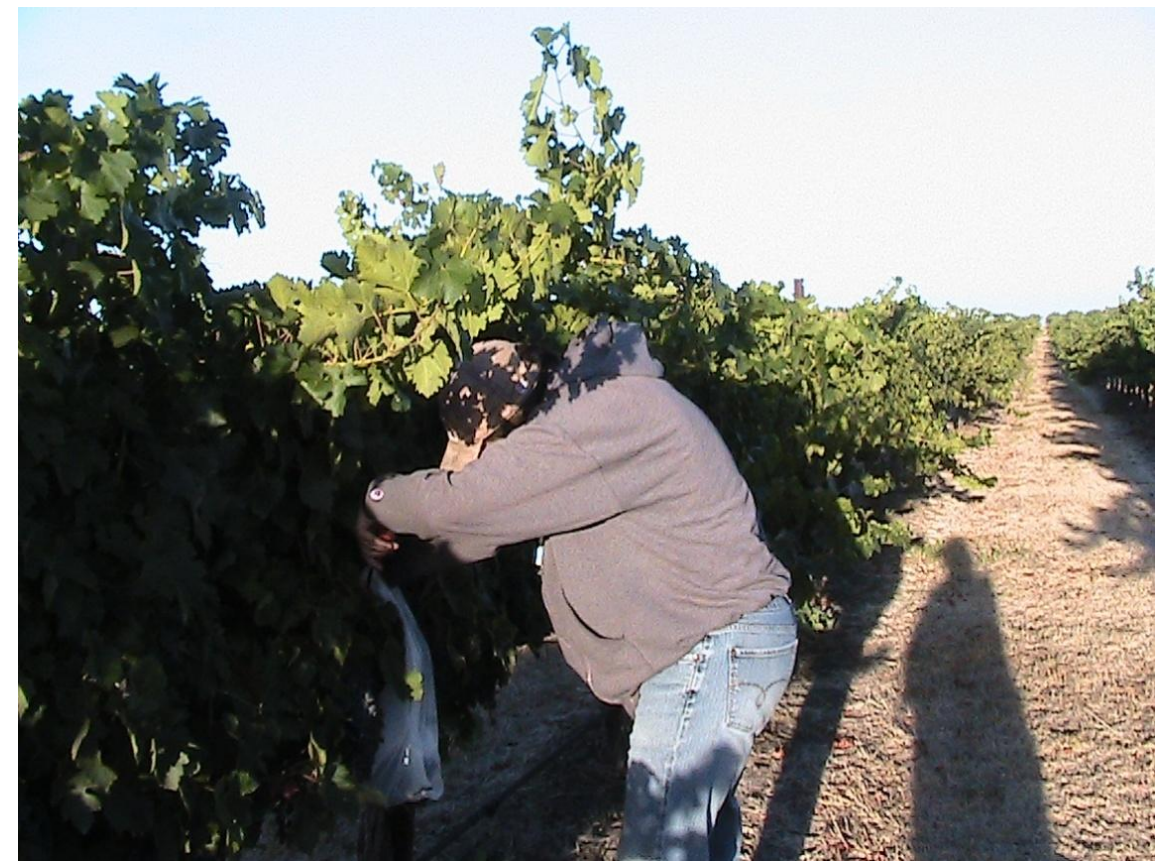

Fig. 6. Sample collection in Block 14 of Derby Wine Estates vineyard (R. Parisi).

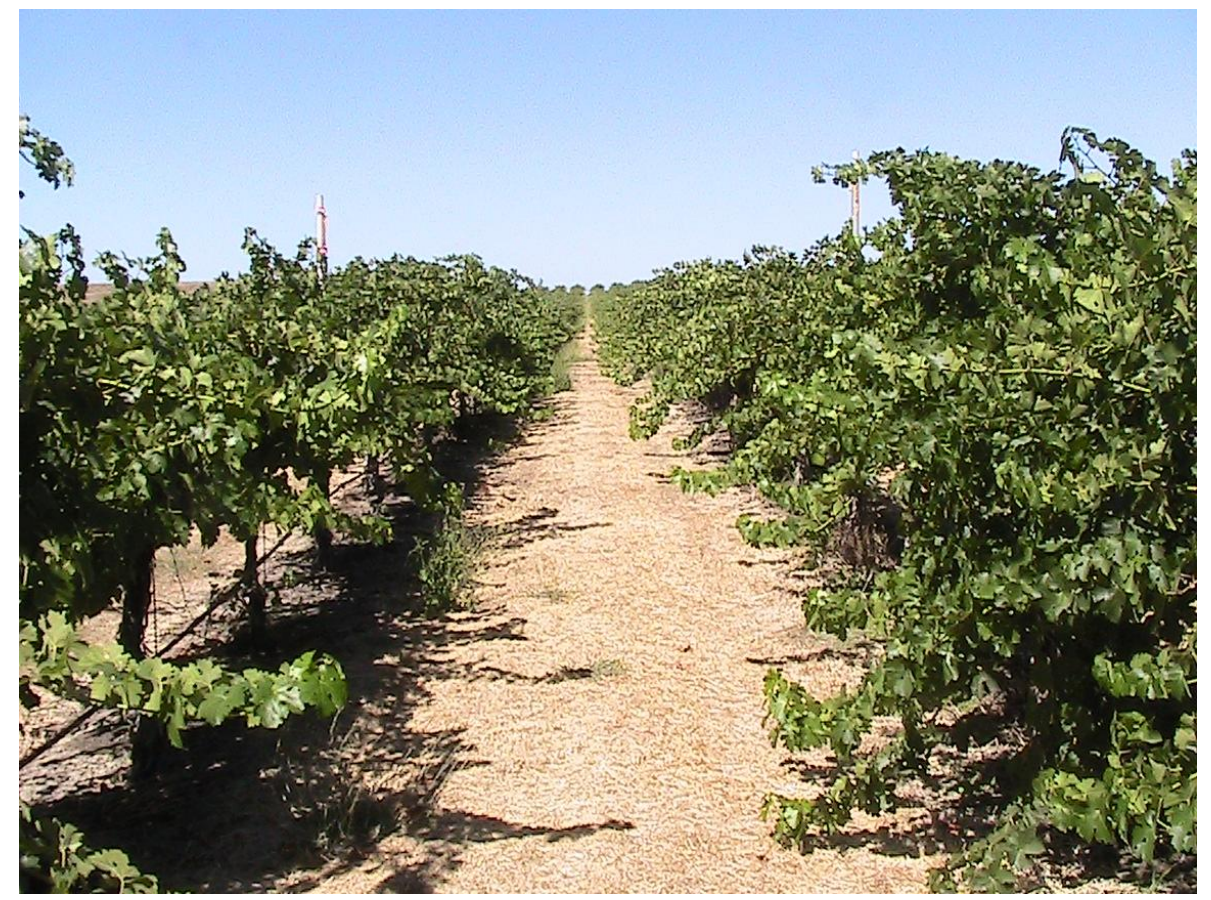

Fig. 7. Block 14 at Derby Wine Estates vineyard indicating the potential vine-tovine variation within a commercial vineyard (T. Fertel). 
vineyard sites around the world due to the vast variances that rootstock, clones, and terroir impart to grape quality. 


\section{CHAPTER VI \\ RECOMMENDATIONS}

In 2009, due to fiscal concerns, samples from treatment replicates were pooled compromising the study. In future studies, monies should be in hand before data collection occurs or contingency plans should be in place if anticipated sources of revenue do not materialize. In addition, a statistician should be consulted when developing the experimental design

Securing help in the vineyard for cluster thinning, sampling and harvest would greatly decrease time in the vineyard and increase efficiency. Better communication with the vineyard and winery managers is needed to secure cluster samples and grapes for wine production. The light into vine canopies should be measured using a spectral radiometer, to determine the correlation between vigor and crop load pertaining to MPs and resveratrol. Tracking MPs before cluster thinning could determine how concentrations accumulate and decrease from berry set to harvest. 


\section{REFERENCES}

Allen, M. 1995. What level of methoxypyrazines is desired in red wines? The flavour perspective of the classic red wines of Bordeaux. The Australian Grapegrower \& Winemaker: Journal of the Australian Wine Industry 381:7-9.

Allen, M.S., and M.J. Lacey. 1993. Methoxypyrazine grape flavour: influence of climate, cultivar, and viticulture. Die Wein-Wissenschaft 48:211-213.

Allen, M.S., M.J. Lacey, R.L.N. Harris, and W.V. Brown. 1991. Contribution of Methoxypyrazines to Sauvignon blanc Wine Aroma. American Journal of Enology and Viticulture 42:109-112.

Bamforth, C. 2008. Grape vs. grain. Cambridge University Press, New York, USA.

Belancic, A., and E. Agosin. 2007. Methoxypyrazines in Grapes and Wines of Vitis vinifera cv. Carmenere. American Journal of Enology and Viticulture 58:462469.

Bogart, K., and L. Bisson. 2006. Persistence of vegetal characters in winegrapes and wine. Available at http://www.practicalwinery.com/marapr06p13.htm (accessed August 11, 2010). Practical Winery and Vineyard.

Bravdo, B., Y. Hepner, C. Loinger, S. Cohen, and H. Tabacman. 1985. Effect of irrigation and crop level on growth, yield and wine quality of Cabernet Sauvignon. American Journal of Enology and Viticulture 36:132-139.

Bravdo, B.A. 2004. Effect of cultural practices and environmental factors on wine production and quality. Acta Horticulturae 652:119-124.

de Boubée, D.R., C.V. Leeuwen, and D. Dubourdieu. 2000. Organoleptic Impact of 2Methoxy-3-isobutylpyrazine on Red Bordeaux and Loire Wines. Effect of Environmental Conditions on Concentrations in Grapes during Ripening. Journal of Agricultural and Food Chemistry 48:4830-4834.

de Boubée, D.R., A.M. Cumsille, M. Pons, and D. Dubourdieu. 2002. Location of 2Methoxy-3-isobutylpyrazine in Cabernet Sauvignon Grape Bunches and Its Extractability during Vinification. American Journal of Enology and Viticulture $53: 1-5$.

Edson, C.E., G.S. Howell, and J.A. Flore. 1995. Influence of crop load on photosynthesis and dry matter partitioning of Seyval grapevines. III. Seasonal changes in dry matter partitioning, vine morphology, yield, and fruit composition. American Journal of Enology and Viticulture 46:478-485.

Ferree, D.C., G.A. Cahoon, D.M. Scurlock, and M.V. Brown. 2003. Effect of time of cluster thinning grapevines. Small Fruits Review 2:3-14.

Galet, P. 2000. General viticulture. English Ed. ed. Oenoplurimedia, Chaintre, France.

Godelmann, R., S. Limmert, and T. Kuballa. 2008. Implementation of headspace solidphase-microextratcion-GC-MS/MS methodology for determination of 3-alkyl-2methoxypyrazines in wine. European Food Research and Technology 227:449461.

Guidoni, S., P. Allara, and A. Schubert. 2002. Effect of Cluster Thinning on Berry Skin Anthocyanin Composition of Vitis vinifera cv. Nebbiolo. American Journal of Enology and Viticulture 53:224-226. 
Hartmann, Peter J., H.M. McNair, B.W. Zoecklein. 2002. Measurement of 3-Alkyl-2Methoxypyrazine by Headspace Solid-Phase Microextraction in Spike Model Wines. American Journal of Enology and Viticulture 53:285-288.

Hashizume, K., and T. Samuta. 1999. Grape maturity and light exposure affect berry methoxypyrazine concentration. American Journal of Enology and Viticulture 50:194-198.

Hepner, Y., and B. Bravdo. 1985. Effect of crop level and drip irrigation schedualing on the potassium status of Cabernet Sauvignon and Carignane vines and its influence on must and wine composition and quality. American Journal of Enology and Viticulture 36:140-147.

Heymann, H., and A.C. Noble. 1987. Descriptive Analysis of Commercial Cabernet Sauvignon Wines from California. American Journal of Enology and Viticulture 38:41-44.

Heymann, H., A.C. Noble, and R.B. Boulton. 1986. Analysis of Methoxypyrazines in Wines. 1. Development of a Quantitative Procedure. Journal of Agriculture and Food Chemistry 34:268-271.

Insel, B. 2008. The U.S. wine industry. Business Economics 43:68.

Jackson, D.I., and P.B. Lombard. 1993. Environmental and management practices affecting grape composition and wine quality - A review. American Journal of Enology and Viticulture 44:409-430.

Keller, M. 2010. The science of grapevines: anatomy and physiology. Elsevier Inc., San Diego, CA.

Keller, M., L.J. Mills, R.L. Wample, and S.E. Spayd. 2005. Cluster Thinning Effects on Three Deficit-Irrigated Vitis vinifera Cultivars. American Journal of Enology and Viticulture 56:91-103.

Kennedy, J.A. 2002. Understanding Grape Berry Development. Available at http://www.practicalwinery.com/JulyAugust02/julaug02p14.htm (accessed August 11, 2010). Practical Winery and Vineyard.

Kennedy, J.A., C. Saucier, and Y. Glories. 2006. Grape and wine phenolics: history and perspective. American Journal of Enology and Viticulture 57:239-248.

Lacey, M.J., M.S. Allen, R.L.N. Harris, and W.V. Brown. 1991. Methoxypyrazines in Sauvignon blanc Grapes and Wines. American Journal of Enology and Viticulture 42:103-108.

Mazza, G., L. Fukumoto, P. Delaquis, B. Girard, and B. Ewert. 1999. Anthocyanins, phenolics, and color of Cabernet Franc, Merlot, and Pinot Noir wines from British Columbia. Journal of Agricultural and Food Chemistry 47:4009-4017.

Morris, J.R., C.A. Sims, R.K. Striegler, S.D. Cackler, and R.A. Donley. 1987. Effects of Cultivar, Maturity, Cluster Thinning, and Excessive Potassium, Fertilization on Yield and Quality or Arkansas Wine Grapes. American Journal of Enology and Viticulture 38:260-264.

Mullins, M.G., A. Bouquet, and L.E. Williams. 1992. Biology of the grapevine. Cambridge University Press, New York, NY.

Noble, A.C., D.L. Elliott-Fisk, and M.S. Allen. 1995. Vegetative Flavor and Methoxypyrazines in Cabernet Sauvignon, p. 226-234, In R. L. Rouseff and M. M. Leahy, (eds.) Fruit flavors. ed. American Chemical Society, Washington, DC. 
Ough, C.S., and R. Nagaoka. 1984. Effect of Cluster Thinning and Vineyard Yields on Grape and Wine Composition and Wine Quality of Cabernet Sauvignon. American Journal of Enology and Viticulture 35:30-34.

Pezet, R., V. Pont, and P. Cuenat. 1994. Method to determine resveratrol and pterostilbene in grape berries and wines using high-performance liquid chromatography and highly sensitive fluorimetric detection. Journal of Chromatography A 663:191-197.

Prajitna, A., I.E. Dami, T.E. Steiner, D.C. Ferree, J.C. Scheerens, and S.J. Schwartz. 2007. Influence of cluster thinning on phenolic composition, resveratrol, and antioxidant capacity in Chambourcin wine. American Journal of Enology and Viticulture 58:346-350.

Preston, L.D., D.E. Block, H. Heymann, G. Soleas, A.C. Noble, and S.E. Ebeler. 2008. Defining Vegetal Aromas in Cabernet Sauvignon Using Sensory and Chemical Evaluations. American Journal of Enology and Viticulture 59:137-145.

Preszler, T., T.M. Schmit, and J.E. Canden Heuvel. 2010. A Model to Establish Economically Sustainable Cluster-Thinning Practices. American Journal of Enology and Viticulture 61:140-146.

Reynolds, A.G., J. Schlosser, D. Sorokowsky, R. Roberts, J. Willwerth, and C. de Savigny. 2007. Magnitude of viticulture and enological effects. II. Relative impacts of cluster thinning and yeast strain on composition and sensory attributes of Chardonnay Musque. American Journal of Enology and Viticulture 58:25-41.

Romero-Pérez, A., M. Ibern-Gómez, M. Lamuela-Raventós, and M. Carme de la TorreBoronat. 1999. Piceid, the major resveratrol derivative in grapes juices. Journal of Agricultural and Food Chemistry 47:1533-1536.

Ryona, I., B.S. Pan, D.S. Intrigliolo, A.N. Lakso, and G.L. Sacks. 2008. Effects of Cluster Light Exposure on 3-Isobutyl-2-methoxypyrazine Accumulation and Degradation Patterns in Red Wine Grapes (Vitis vinifera L. Cv. Cabernet Franc). Journal of Agricultural and Food Chemistry 56:10838-10846.

Sala, C., O. Busto, J. Guasch, and F. Zamora. 2004. Influence of vine training and sunlight exposure on the 3-alkyl-2-methoxypyrazines content in musts and wines from the Vitis vinifera variety Cabernet Sauvignon. Journal of Agricultural and Food Chemistry 52:3492-3497.

Sala, C., O. Busto, J. Guasch, and F. Zamora. 2005. Contents of 3-alkyl-2methoxypyrazines in musts and wines from Vitis vinifera variety Cabernet Sauvignon: influence of irrigation and plantation density. Journal of Science of Food and Agriculture 85:1131-1136.

Scheiner, J.J., G.L. Sacks, and J.E. Vanden Heuvel. 2009. How viticultural factors affect methoxypyrazines: water levels, cluster shading and temperature all play roles. Wines \& Vines November:113-116.

Smart, R., and M. Robinson. 1991. Sunlight into wine: a handbook for winegrape canopy management. Winetitles, Adelaide, Australia.

Smithyman, R.P., G.S. Howell, and D.P. Miller. 1998. The use of competition for carbohydrates among vegetative and reproductive sinks to reduce fruit set and Botrytis bunch rot in Seyval blanc grapevines. American Journal of Enology and Viticulture 49:163-170. 
Spayd, S.E., C.W. Nagel, L.D. Hayrynen, and M. Ahmedullah. 1987. Effect of Freezing Fruit on the Composition of Musts and Wines. American Journal of Enology and Viticulture 38:243-245.

This, P., T. Lacombe, and M.R. Thomas. 2006. Historical origins and genetic diversity of wine grapes. TRENDS in Genetics 22:511-519.

Udenigwe, C.C., V.R. Ramprasath, R.E. Aluko, and P.J. Jones. 2008. Potential of resveratrol in anticancer and anti-inflammatory therapy. Nutrition Reviews 66:445-454.

Weaver, R.J., and R.M. Pool. 1973. Effect of time of thinning on berry size of girdled, gibberellin treated 'Thompson Seedless' grapes. Vitis 12:97-99.

Winkler, A.J., J.A. Cook, W.M. Kliewer, and L.A. Lider. 1974. General viticulture. University of California Press, Los Angeles, CA.

Woraratphoka, J., K. Intarapichet, and K. Indrapichate. 2007. Phenolic compounds and antioxidative properties of selected wines from the northeast of Thailand. Food Chemistry 104:1485-1490.

Website

University of California, Agriculture and Natural Resources UC IPM Online: Statewide Pest Management Program. 2011. http://www.ipm.ucdavis.edu.

Software

Minitab® Inc. 2011. State College, PA. 
APPENDICES 


\section{APPENDIX A}

Table 5. Degree-days accumulated in Paso Robles, CA, with a lower limit of $50^{\circ} \mathrm{F}$ (http://www.ipm.ucdavis.edu).

\begin{tabular}{lll}
\hline Date & 2009 & 2010 \\
\hline April 1 & 9.37 & 4.38 \\
May 1 & 286.53 & 216.72 \\
June 1 & 809.75 & 564.23 \\
July 1 & 1285.44 & 1131.08 \\
August 1 & 2034.06 & $17-2.16$ \\
September 1 & 2730.95 & 2298.08 \\
October 1 & 3374.71 & 2871.61 \\
October 25 & 3675.44 & 3190.62 \\
November 2 & $\mathrm{n} / \mathrm{a}$ & 3261.52 \\
\hline
\end{tabular}

Table 6. Precipitation in Paso Robles, CA from December $1^{\text {st }}$ of the previous year to June $1^{\text {st }}$ (http://www.ipm.ucdais.edu).

\begin{tabular}{cc}
\hline Year & Precipitation $(\mathrm{cm})$ \\
\hline 2009 & 19.28 \\
2010 & 42.93 \\
\hline
\end{tabular}




\section{APPENDIX B}

Table 7. Randomly selected treatment order, from east to west, of Cabernet sauvignon.

\begin{tabular}{llllll}
\hline Vine Row & \multicolumn{5}{c}{ Treatment Order $^{\mathrm{z}}$} \\
\hline 52 & C & GT & LT & ST & MT \\
53 & LT & MT & C & GT & ST \\
54 & MT & LT & ST & GT & C \\
55 & GT & MT & LT & ST & C \\
& \\
& \\
severely-thinned. &
\end{tabular}

Table 8. 2009 berries per cluster from Cabernet sauvignon bunches, with each number representing the number of berries on a single cluster.

\begin{tabular}{lllllll}
\hline \multicolumn{7}{l}{ Number of berries per single cluster } \\
\hline 63 & 125 & 186 & 75 & 55 & 122 & 81 \\
133 & 74 & 42 & 112 & 158 & 123 & 121 \\
25 & 35 & 58 & 132 & 116 & 153 & 79 \\
85 & 163 & 117 & 153 & 95 & 60 & 88 \\
122 & 77 & 62 & 48 & 75 & 156 & 127 \\
29 & 116 & 117 & 131 & 119 & 75 & 176 \\
187 & 147 & 168 & 122 & 120 & 73 & 42 \\
\hline
\end{tabular}


Table 9. 2009 total and average cluster and berry weights of Cabernet sauvignon.

\begin{tabular}{lllllllllllll}
\hline & \multicolumn{3}{c}{ August 31 } & \multicolumn{3}{c}{ September 21 } & \multicolumn{5}{c}{ October 26 } \\
\hline Treatment $^{\mathrm{z}}$ & $\mathrm{NC}^{\mathrm{y}}$ & $\mathrm{TCW}^{\mathrm{x}}$ & $\mathrm{ACW}^{\mathrm{w}}$ & $\mathrm{ABW}^{\mathrm{v}}$ & $\mathrm{NC}$ & $\mathrm{TCW}$ & $\mathrm{ACW}$ & $\mathrm{ABW}$ & $\mathrm{NC}$ & $\mathrm{TCW}$ & $\mathrm{ACW}$ & $\mathrm{ABW}$ \\
\hline $\mathrm{C}$ & 48 & 5.76 & 120 & 1.11 & 20 & 2.25 & 110 & 1.09 & 40 & 3.75 & 90 & 0.90 \\
$\mathrm{LT}$ & 21 & 4.83 & 230 & 2.17 & 20 & 2.60 & 130 & 1.25 & 40 & 4.00 & 100 & 0.96 \\
MT & 26 & 4.16 & 160 & 1.57 & 20 & 2.50 & 120 & 1.20 & 40 & 3.50 & 90 & 0.85 \\
$\mathrm{GT}$ & 35 & 4.20 & 120 & 1.16 & 20 & 2.30 & 120 & 1.11 & 40 & 3.75 & 90 & 0.09 \\
$\mathrm{ST}$ & 35 & 3.50 & 100 & 0.91 & 20 & 2.30 & 120 & 1.11 & 40 & 4.00 & 100 & 0.96 \\
\hline
\end{tabular}

${ }^{\bar{z}}$ C, unthinned; LT, lightly-thinned; MT, moderately-thinned; GT, greatly-thinned; ST, severely-thinned.

${ }^{\mathrm{y}}$ Number of clusters sampled.

${ }^{\mathrm{x}}$ Total cluster weights in $\mathrm{kg}$.

${ }^{\mathrm{w}}$ Average cluster weights in $\mathrm{g}$.

${ }^{\mathrm{v}}$ Average berry weight in $\mathrm{g}$.

Table 10. 2009 soluble solids, $\mathrm{pH}$, and titratable acidity of Cabernet sauvignon.

\begin{tabular}{|c|c|c|c|c|c|c|c|c|c|}
\hline \multirow[b]{2}{*}{ Treatment $^{\mathrm{z}}$} & \multicolumn{3}{|c|}{ August 31} & \multicolumn{3}{|c|}{ September 21} & \multicolumn{3}{|c|}{ October 26} \\
\hline & $\mathrm{SS}^{\mathrm{y}}$ & $\mathrm{pH}$ & $\mathrm{TA}^{\mathrm{x}}$ & $\mathrm{SS}$ & $\mathrm{pH}$ & TA & $\mathrm{SS}$ & $\mathrm{pH}$ & TA \\
\hline $\mathrm{C}$ & 18.0 & 3.22 & 8.3 & 20.6 & 3.39 & 6.0 & 22.6 & 3.63 & 5.4 \\
\hline LT & 18.0 & 3.14 & 8.7 & 20.6 & 3.42 & 5.6 & 22.6 & 3.47 & 5.7 \\
\hline MT & 18.1 & 3.14 & 9.4 & 21.2 & 3.45 & 5.9 & 21.6 & 3.52 & 9.6 \\
\hline GT & 19.0 & 3.20 & 8.2 & 21.2 & 3.43 & 5.8 & 22.4 & 3.54 & 9.2 \\
\hline ST & 20.0 & 3.25 & 7.5 & 21.3 & 3.51 & 5.0 & 23.0 & 3.65 & 8.5 \\
\hline
\end{tabular}

${ }^{\mathrm{Z}} \mathrm{C}$, unthinned; LT, lightly-thinned; MT, moderately-thinned; GT, greatly-thinned; ST, severely-thinned.

${ }^{\mathrm{y}}$ Soluble solids expressed as ${ }^{\circ}$ Brix.

${ }^{\mathrm{x}}$ Titratable acidity as $\mathrm{g} / \mathrm{L}$ total titratable acidity. 
Table 11. 2009 methoxypyrazine and resveratrol data of Cabernet sauvignon.

\begin{tabular}{|c|c|c|c|c|c|}
\hline \multirow[b]{2}{*}{ Treatment $^{\mathrm{z}}$} & \multicolumn{3}{|c|}{ 3-Isobutly-2-methoxypyrazin (ng/L) } & \multicolumn{2}{|c|}{ Resveratrol (mg/L) } \\
\hline & August $31^{\mathrm{y}}$ & September $21^{\mathrm{y}}$ & October $26^{\mathrm{x}}$ & August $31^{\mathrm{y}}$ & September $21^{\mathrm{y}}$ \\
\hline $\mathrm{C}$ & 4.4 & $<3.0$ & $<5.0$ & $<0.1$ & $<0.1$ \\
\hline LT & 4.3 & $<3.0$ & $<5.0$ & $<0.1$ & $<0.1$ \\
\hline MT & 6.2 & $<3.0$ & $<5.0$ & $<0.1$ & $<0.1$ \\
\hline GT & 7.0 & $<3.0$ & $<5.0$ & $<0.1$ & $<0.1$ \\
\hline ST & 5.1 & $<3.0$ & $<5.0$ & $<0.1$ & $<0.1$ \\
\hline
\end{tabular}

${ }^{\mathrm{z}} \mathrm{C}$, unthinned; LT, lightly-thinned; MT, moderately-thinned; GT, greatly-thinned; ST, severely-thinned.

${ }^{\mathrm{y}}$ Juice samples.

${ }^{\mathrm{x}}$ Berry samples.

Table 12. Preference rankings of the five 2009 Cabernet sauvignon wines.

\begin{tabular}{|c|c|c|c|c|c|c|c|c|c|c|c|c|c|c|c|c|c|c|c|c|c|c|c|c|}
\hline $\mathrm{J}^{\mathrm{Z}}$ & 1 & 2 & 3 & 4 & 5 & 6 & 7 & 8 & 9 & 10 & 11 & 12 & 13 & 14 & 15 & 16 & 17 & 18 & 19 & 20 & 21 & 22 & 23 & 24 \\
\hline \multicolumn{25}{|c|}{ Treatment $^{\mathrm{y}}$} \\
\hline $\mathrm{C}$ & 4 & 5 & 2 & 3 & 1 & 1 & 1 & 3 & 2 & 3 & 3 & 2 & 2 & 2 & 5 & 1 & 1 & 3 & 3 & 2 & 3 & 1 & 5 & 3 \\
\hline LT & 3 & 1 & 4 & 5 & 5 & 2 & 3 & 2 & 4 & 4 & 2 & 4 & 3 & 1 & 1 & 5 & 4 & 4 & 5 & 3 & 5 & 5 & 1 & 2 \\
\hline MT & 1 & 3 & 1 & 4 & 4 & 3 & 2 & 5 & 3 & 2 & 1 & 1 & 1 & 4 & 4 & 2 & 5 & 5 & 2 & 1 & 1 & 2 & 3 & 4 \\
\hline GT & 5 & 4 & 3 & 1 & 3 & 4 & 4 & 1 & 1 & 1 & 4 & 5 & 5 & 3 & 3 & 3 & 3 & 2 & 1 & 4 & 2 & 4 & 2 & 1 \\
\hline ST & 2 & 2 & 5 & 2 & 2 & 5 & 5 & 4 & 5 & 5 & 5 & 3 & 4 & 5 & 2 & 4 & 2 & 1 & 4 & 5 & 4 & 3 & 4 & 5 \\
\hline
\end{tabular}

${ }^{\mathrm{z}}$ J, judge.

${ }^{\mathrm{y}} \mathrm{C}$, unthinned; LT, lightly-thinned; MT, moderately-thinned; GT, greatly-thinned; ST, severely-thinned. 
Table 13. 2010 berries per cluster counts at lag phase of Cabernet sauvignon.

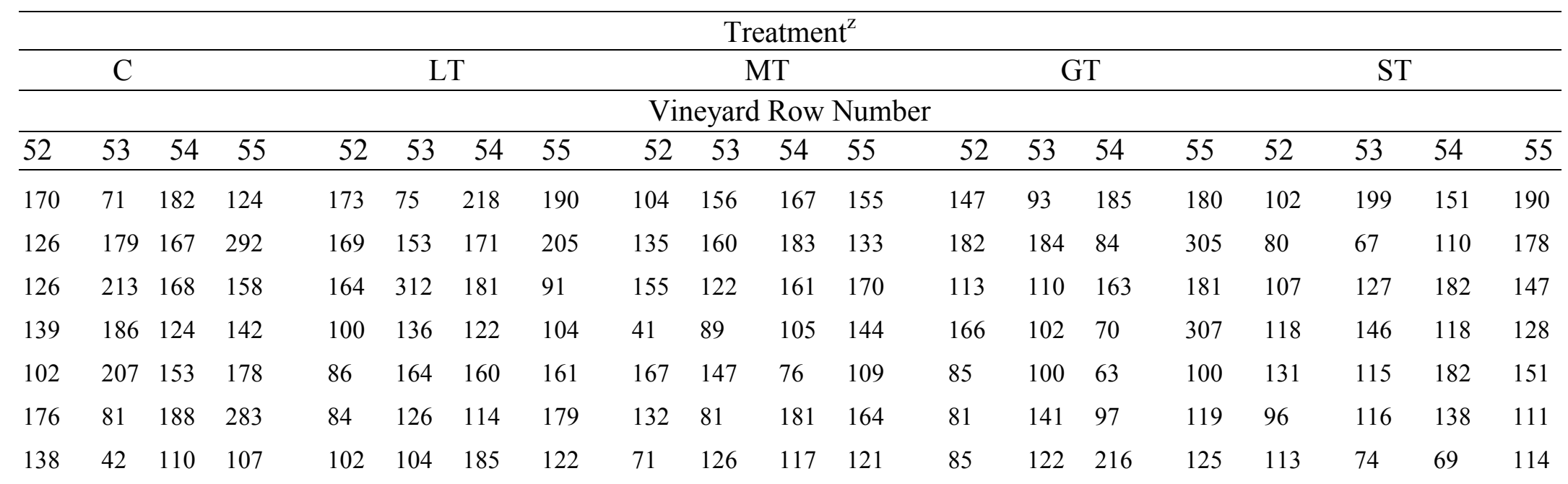

${ }^{\mathrm{z}} \mathrm{C}$, unthinned; LT, lightly-thinned; MT, moderately-thinned; GT, greatly-thinned; ST, severely-thinned.

Table 14. 2010 cluster counts per treatment.

\begin{tabular}{lllll}
\hline \multicolumn{5}{c}{ Vineyard Row Number } \\
\hline Treatment $^{\mathrm{z}}$ & 52 & 53 & 54 & 55 \\
\hline $\mathrm{C}$ & 179 & 141 & 121 & 141 \\
LT & 158 & 123 & 117 & 127 \\
MT & 152 & 126 & 105 & 121 \\
GT & 125 & 107 & 106 & 100 \\
ST & 96 & 111 & 194 & 85 \\
\hline${ }^{\mathrm{z}} \mathrm{C}$, unthinn
\end{tabular}

${ }^{\mathrm{z}} \mathrm{C}$, unthinned; LT, lightly-thinned; MT, moderately-thinned; GT, greatly-thinned; ST, severely-thinned. 
Table 15. 2010 cluster weights of Cabernet sauvignon in $\mathrm{kg}$.

\begin{tabular}{lccccccccccc}
\hline & \multicolumn{9}{c}{ September 2 } & \multicolumn{9}{c}{ September 29 } \\
\hline & \multicolumn{9}{c}{ Vineyard Row Number } \\
\hline Treatment $^{\mathrm{z}}$ & 52 & 53 & 54 & 55 & 52 & 53 & 54 & 55 & 52 & 53 & 54 \\
\hline C & 0.91 & 0.91 & 1.25 & 0.91 & 1.13 & 1.03 & 1.16 & 1.27 & 0.95 & 1.28 & 1.06 \\
LT & 1.25 & 1.13 & 0.91 & 1.02 & 1.09 & 1.19 & 1.27 & 0.83 & 0.94 & 1.14 & 1.08 \\
MT & 1.02 & 1.02 & 0.91 & 0.91 & 1.04 & 0.88 & 0.85 & 0.84 & 1.10 & 1.14 & 1.08 \\
GT & 1.13 & 0.91 & 1.13 & 1.02 & 1.12 & 1.06 & 0.99 & 1.16 & 1.23 & 0.96 & 1.01 \\
ST & 0.79 & 0.91 & 1.25 & 0.91 & 1.12 & 0.92 & 1.23 & 0.96 & 1.26 & 0.90 & 0.96 \\
\hline
\end{tabular}

${ }^{\bar{z}} \mathrm{C}$, unthinned; LT, lightly-thinned; MT, moderately-thinned; GT, greatly-thinned; ST, severely-thinned.

Table 16. September 2, 2010 berry chemistry data of Cabernet sauvignon.

\begin{tabular}{|c|c|c|c|c|c|c|c|c|c|c|c|c|}
\hline \multirow[b]{3}{*}{ Treatment $^{\mathrm{Z}}$} & \multicolumn{12}{|c|}{ Vineyard Row Number } \\
\hline & \multicolumn{3}{|c|}{52} & \multicolumn{3}{|c|}{53} & \multicolumn{3}{|c|}{54} & \multicolumn{3}{|c|}{55} \\
\hline & $\mathrm{SS}^{\mathrm{y}}$ & $\mathrm{pH}$ & $\mathrm{TA}^{\mathrm{x}}$ & $\mathrm{SS}$ & $\mathrm{pH}$ & TA & $\mathrm{SS}$ & $\mathrm{pH}$ & TA & $\mathrm{SS}$ & $\mathrm{pH}$ & $\mathrm{TA}$ \\
\hline $\mathrm{C}$ & 12.4 & 3.35 & 7.91 & 16.6 & 3.32 & 8.08 & 15.9 & 3.28 & 8.63 & 16.2 & 3.23 & 8.97 \\
\hline $\mathrm{LT}$ & 14.3 & 3.21 & 9.68 & 13.2 & 3.24 & 8.97 & 14.0 & 3.08 & 11.24 & 12.6 & 3.22 & 8.33 \\
\hline MT & 14.3 & 3.27 & 7.58 & 15.2 & 3.22 & 9.01 & 16.5 & 3.23 & 9.18 & 17.0 & 3.34 & 9.29 \\
\hline GT & 14.1 & 3.28 & 8.27 & 17.0 & 3.41 & 7.32 & 18.0 & 3.28 & 7.43 & 17.0 & 3.29 & 8.58 \\
\hline ST & 16.0 & 3.28 & 8.32 & 18.3 & 3.47 & 6.75 & 17.7 & 3.37 & 6.90 & 18.2 & 3.45 & 7.45 \\
\hline
\end{tabular}

${ }^{\mathrm{z}} \mathrm{C}$, unthinned; LT, lightly-thinned; MT, moderately-thinned; GT, greatly-thinned; ST, severely-thinned.

${ }^{\mathrm{y}}$ Soluble solids expressed as ${ }^{\circ}$ Brix.

${ }^{\mathrm{x}}$ Titratable acidity as $\mathrm{g} / \mathrm{L}$ total titratable acidity. 
Table 17. September 21, 2010 berry chemistry data of Cabernet sauvignon.

\begin{tabular}{|c|c|c|c|c|c|c|c|c|c|c|c|c|}
\hline \multirow[b]{3}{*}{ Treatment $^{\mathrm{Z}}$} & \multicolumn{12}{|c|}{ Vineyard Row Number } \\
\hline & \multicolumn{3}{|c|}{52} & \multicolumn{3}{|c|}{53} & \multicolumn{3}{|c|}{54} & \multicolumn{3}{|c|}{55} \\
\hline & $\mathrm{SS}^{\mathrm{y}}$ & $\mathrm{pH}$ & $\mathrm{TA}^{\mathrm{x}}$ & $\mathrm{SS}$ & $\mathrm{pH}$ & TA & $\mathrm{SS}$ & $\mathrm{pH}$ & TA & $\mathrm{SS}$ & $\mathrm{pH}$ & TA \\
\hline $\mathrm{C}$ & 17.8 & 3.74 & 5.60 & 19.8 & 3.77 & 5.05 & 18.8 & 3.83 & 4.62 & 18.2 & 3.71 & 4.55 \\
\hline $\mathrm{LT}$ & 19.0 & 3.61 & 5.29 & 18.7 & 3.69 & 5.10 & 16.0 & 3.71 & 3.52 & 18.3 & 3.72 & 4.69 \\
\hline MT & 19.5 & 3.79 & 4.94 & 19.3 & 3.78 & 5.49 & 17.4 & 3.76 & 2.12 & 18.3 & 3.65 & 4.47 \\
\hline GT & 18.0 & 3.83 & 5.10 & 21.0 & 3.93 & 4.76 & 18.4 & 3.83 & 3.67 & 19.6 & 3.75 & 4.60 \\
\hline ST & 19.2 & 3.65 & 4.77 & 18.8 & 3.96 & 4.69 & 19.8 & 3.82 & 3.77 & 20.0 & 3.87 & 4.27 \\
\hline
\end{tabular}

${ }^{\mathrm{z}} \mathrm{C}$, unthinned; LT, lightly-thinned; MT, moderately-thinned; GT, greatly-thinned; ST, severely-thinned.

${ }^{\mathrm{y}}$ Soluble solids expressed as ${ }^{\circ}$ Brix.

${ }^{\mathrm{x}}$ Titratable acidity as $\mathrm{g} / \mathrm{L}$ total titratable acidity.

Table 18. November 2, 2010 sample date 3 berry chemistry data of Cabernet sauvignon.

\begin{tabular}{|c|c|c|c|c|c|c|c|c|c|}
\hline \multirow[b]{3}{*}{ Treatment $^{\mathrm{z}}$} & \multicolumn{9}{|c|}{ Vineyard Row Number } \\
\hline & \multicolumn{3}{|c|}{52} & \multicolumn{3}{|c|}{53} & \multicolumn{2}{|c|}{54} & \\
\hline & $\mathrm{SS}^{\mathrm{y}}$ & $\mathrm{pH}$ & $\mathrm{TA}^{\mathrm{x}}$ & $\mathrm{SS}$ & $\mathrm{pH}$ & TA & $\mathrm{SS}$ & $\mathrm{pH}$ & TA \\
\hline $\mathrm{C}$ & 20.2 & 3.86 & 4.82 & 22.6 & 4.02 & 3.94 & 23.2 & 4.05 & 3.47 \\
\hline LT & 20.8 & 3.78 & 3.89 & 22.0 & 3.87 & 4.62 & 22.6 & 3.75 & 4.17 \\
\hline MT & 22.0 & 3.93 & 3.47 & 23.0 & 4.16 & 4.11 & 23.5 & 4.19 & 3.62 \\
\hline GT & 22.4 & 3.94 & 4.00 & 23.5 & 4.22 & 3.30 & 23.3 & 4.04 & 4.01 \\
\hline ST & 22.7 & 4.02 & 3.44 & 23.6 & 4.23 & 3.06 & 23.5 & 4.19 & 4.21 \\
\hline
\end{tabular}

${ }^{\bar{z}} \mathrm{C}$, unthinned; LT, lightly-thinned; MT, moderately-thinned; GT, greatly-thinned; ST, severely-thinned.

${ }^{\mathrm{y}}$ Soluble solids expressed as ${ }^{\circ}$ Brix. ${ }^{\mathrm{x}}$ Titratable acidity as $\mathrm{g} / \mathrm{L}$ total titratable acidity. 
Table 19. 2010 methoxypyrazine data of Cabernet sauvignon, in $\mathrm{ng} / \mathrm{kg}$ total methoxypyrazines.

\begin{tabular}{|c|c|c|c|c|c|c|c|c|c|c|c|}
\hline \multirow[b]{3}{*}{ Treatment $^{\mathrm{z}}$} & \multicolumn{4}{|c|}{ September 2} & \multicolumn{4}{|c|}{ September 29} & \multicolumn{3}{|c|}{ November 2} \\
\hline & \multicolumn{11}{|c|}{ Vineyard Row Number } \\
\hline & 52 & 53 & 54 & 55 & 52 & 53 & 54 & 55 & 52 & 53 & 54 \\
\hline $\mathrm{C}$ & 97.0 & 56.0 & 42.0 & 58.8 & 34.6 & 20.4 & 17.3 & 23.9 & 13.4 & 7.6 & 8.3 \\
\hline $\mathrm{LT}$ & 115.2 & 60.2 & 74.9 & 60.9 & 35.1 & 27.2 & 17.6 & 23.7 & 6.8 & $<5.0$ & 5.6 \\
\hline $\mathrm{MT}$ & 75.7 & 89.3 & 57.6 & 44.5 & 29.1 & 29.2 & 31.7 & 24.9 & 9.9 & 14.5 & 7.3 \\
\hline GT & 85.8 & 70.7 & 75.4 & 59.3 & 36.4 & 41.4 & 22.6 & 29.2 & 8.4 & 10.5 & 8.1 \\
\hline ST & 67.9 & 83.1 & 40.0 & 59.3 & 42.9 & 43.4 & 19.8 & 31.0 & 12.4 & 13.5 & 14.7 \\
\hline
\end{tabular}

${ }^{\bar{z}} \mathrm{C}$, unthinned; LT, lightly-thinned; MT, moderately-thinned; GT, greatly-thinned; ST, severely-thinned. 


\section{APPENDIX C \\ Preference Ranking Scorecard}

Name:

1. Write the code for the sample in the space provided below.

2. Please rinse your mouth with water and expectorate before starting

3. You may rinse at any time during the test.

4. Please taste the 5 samples in the order presented, from left to right.

5. You may re-taste the samples once you have tried all of them.

RANK THE SAMPLES FROM MOST PREFERRED TO LEAST PREFERRED USING THE FOLLOWING NUMBERS.

$1=$ MOST PREFERRED 5 = LEAST PREFERRED

\begin{tabular}{|l|l|}
\hline Sample Code & $\begin{array}{c}\text { Rank (1 to 5) } \\
\text { (Ties not allowed) }\end{array}$ \\
\hline & \\
\hline & \\
\hline & \\
\hline & \\
\hline
\end{tabular}




\section{APPENDIX D}

ETS Data Reports

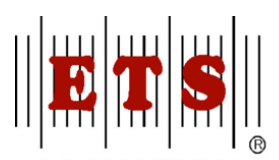

LABORATORIES

\section{REPORT LABORATORY \# 402554: 2009 Resveratrol Sample Date 1}

Derby Wine Estates

Attn: Tiffinee Vierra

Post Office Box 5000

Paso Robles, CA 93447
Samples Received1 September 2009 11:24 am

Analysis Reported2 September 2009 11:33 am

\begin{tabular}{llll} 
Analyte & Result & Analysis Date & Method Reference \\
\hline $\mathbf{9 0 9 0 1 0 1 5 8 ~ \# 1}$ & $<0.1 \mathrm{mg} / \mathrm{L}$ & $9 / 2 / 09$ \\
resveratrol (Cis+trans) (HPLC) & $<0.1 \mathrm{mg} / \mathrm{L}$ & $9 / 2 / 09$ \\
$\begin{array}{l}\mathbf{9 0 9 0 1 0 1 5 9 ~ \# 2} \\
\text { resveratrol (cis+trans) (HPLC) }\end{array}$ & $<0.1 \mathrm{mg} / \mathrm{L}$ & $9 / 2 / 09$ \\
$\mathbf{9 0 9 0 1 0 1 6 0 ~ \# 3}$ & & \\
resveratrol (cis+trans) (HPLC) & $<0.1 \mathrm{mg} / \mathrm{L}$ & $9 / 2 / 09$ \\
$\mathbf{9 0 9 0 1 0 1 6 1 \# 4}$ & & $9 / 2 / 09$ \\
resveratrol (cis+trans) (HPLC) & $0.1 \mathrm{mg} / \mathrm{L}$ & \\
$\mathbf{9 0 9 0 1 0 1 6 2 ~ \# 5}$ & &
\end{tabular}

The results in this report relate only to samples as submitted.

This report is intended only for the individual or entity to which it is addressed and may contain information that is privileged, confidential, and exempt from disclosure under applicable law. If the reader of this report is not the intended recipient or the person responsible for delivering this report to the intended recipient, you are hereby notified that any dissemination, distribution, or copying of this report is strictly prohibited. If you have received this report in error, please notify us immediately by telephone and return the original report to us at the address below via postal services. This report shall not be reproduced except in full, without the written approval of ETS Laboratories.

Gordon Burns

Technical Director

Page 1 of 1

ETS Laboratories I 899 Adams St.I Suite A I St. Helena CA 94574 I Tel: 707.963.4806 I Fax: 707.963.1054 I info@etslabs.com I www.etslabs.com 


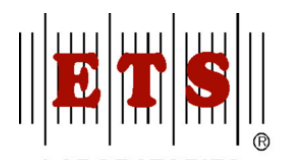

LABORATORIES

\section{REPORT LABORATORY \# 406226: 2009 Resveratrol Sample Date 2}

Derby Wine Estates

Attn: Tiffinee Vierra

Post Office Box 5000

Paso Robles, CA 93447
Samples Received: 22 September 2009 10:00 am Analysis Reported: 24 September 2009 10:49 am

\begin{tabular}{llll} 
Analyte & Result & Analysis Date & Method Reference \\
\hline $\mathbf{9 0 9 2 2 0 0 7 5 ~ 1}$ & $<0.1 \mathrm{mg} / \mathrm{L}$ & $9 / 24 / 09$ \\
resveratrol (cis+trans) (HPLC) & $<0.1 \mathrm{mg} / \mathrm{L}$ & $9 / 24 / 09$ \\
$\mathbf{9 0 9 2 2 0 0 7 6 ~ 2}$ & & \\
resveratrol (cis+trans) (HPLC) & $<0.1 \mathrm{mg} / \mathrm{L}$ & $9 / 24 / 09$ \\
$\mathbf{9 0 9 2 2 0 0 7 7 ~ 3}$ & $<0.1 \mathrm{mg} / \mathrm{L}$ & $9 / 24 / 09$ \\
resveratrol (cis+trans) (HPLC) & & \\
$\mathbf{9 0 9 2 2 0 0 7 8 ~ 4}$ & $<0.1 \mathrm{mg} / \mathrm{L}$ & $9 / 24 / 09$ \\
resveratrol (cis+trans) (HPLC) & &
\end{tabular}

The results in this report relate only to samples as submitted.

This report is intended only for the individual or entity to which it is addressed and may contain information that is privileged, confidential, and exempt from disclosure under applicable law. If the reader of this report is not the intended recipient or the person responsible for delivering this report to the intended recipient, you are hereby notified that any dissemination, distribution, or copying of this report is strictly prohibited. If you have received this report in error, please notify us immediately by telephone and return the original report to us at the address below via postal services. This report shall not be reproduced except in full, without the written approval of ETS Laboratories.

Gordon Burns

Technical Director

Page 1 of 1

ETS Laboratories I 899 Adams St.I Suite A I St. Helena CA 94574 | Tel: 707.963.4806 I Fax: 707.963.1054 I info@etslabs.com I www.etslabs.com 


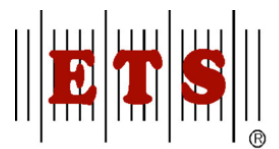

LABORATORIES

\section{REPORT LABORATORY \# 483839: 2009 Wine Resveratrol}

Derby Wine Estates

Attn: Tiffinee Vierra

Post Office Box 5000

Paso Robles, CA 93447
Samples Received:25 January 2011 2:18 pm

Analysis Reported: 27 January 2011 12:46 pm

\begin{tabular}{llll} 
Analyte & Result & Analysis Date & Method Reference \\
\hline $\mathbf{1 0 1 2 5 0 5 1 7 ~ 1 4 8 7}$ & & \\
resveratrol (cis+trans) (HPLC) & $<0.1 \mathrm{mg} / \mathrm{L}$ & $1 / 27 / 11$ \\
resveratrol (cis+trans) (HPLC) & $<0.4 \mathrm{micromoles} / \mathrm{L}$ & $1 / 27 / 11$ \\
$\mathbf{1 0 1 2 5 0 5 1 8 \quad 3 5 6 4}$ & & \\
resveratrol (cis+trans) (HPLC) & $<0.1 \mathrm{mg} / \mathrm{L}$ & $1 / 27 / 11$ \\
resveratrol (cis+trans) (HPLC) & $<0.4 \mathrm{micromoles} / \mathrm{L}$ & $1 / 27 / 11$ \\
$\mathbf{1 0 1 2 5 0 5 1 9 \quad 4 5 9 6}$ & & $1 / 27 / 11$ \\
resveratrol (cis+trans) (HPLC) & $<0.1 \mathrm{mg} / \mathrm{L}$ & $1 / 27 / 11$ \\
resveratrol (cis+trans) (HPLC) & $<0.4 \mathrm{micromoles} / \mathrm{L}$ & \\
$\mathbf{1 0 1 2 5 0 5 2 0 8 7 4 1}$ & $<0.1 \mathrm{mg} / \mathrm{L}$ & $1 / 27 / 11$ \\
resveratrol (cis+trans) (HPLC) & $<0.4 \mathrm{micromoles} / \mathrm{L}$ & $1 / 27 / 11$ \\
resveratrol (cis+trans) (HPLC) & & \\
$\mathbf{1 0 1 2 5 0 5 2 1} \mathbf{9 4 1 1}$ & $<0.1 \mathrm{mg} / \mathrm{L}$ & $1 / 27 / 11$ \\
resveratrol (cis+trans) (HPLC) & $<0.4 \mathrm{micromoles} / \mathrm{L}$ & $1 / 27 / 11$
\end{tabular}

The results in this report relate only to samples as submitted.

This report is intended only for the individual or entity to which it is addressed and may contain information that is privileged, confidential, and exempt from disclosure under applicable law. If the reader of this report is not the intended recipient or the person responsible for delivering this report to the intended recipient, you are hereby notified that any dissemination, distribution, or copying of this report is strictly prohibited. If you have received this report in error, please notify us immediately by telephone and return the original report to us at the address below via postal services. This report shall not be reproduced except in full, without the written approval of ETS Laboratories.

Gordon Burns

Technical Director

Page 1 of 1

ETS Laboratories I 899 Adams St.I Suite A I St. Helena CA 94574 I Tel: 707.963.4806 I Fax: 707.963.1054 I info@etslabs.com I www.etslabs.com 


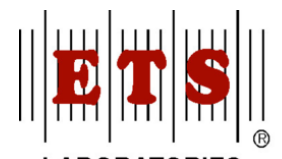

LABORATORIES

\section{REPORT LABORATORY \# 402555: 2009 MPs Sample Date 1}

Derby Wine Estates

Attn: Tiffinee Vierra

Post Office Box 5000

Paso Robles, CA 93447
Samples Received:1 September 2009 11:28 am Analysis Reported: 3 September 2009 12:00 pm

\begin{tabular}{|c|c|c|c|}
\hline Analyte & Result & Analysis Date & Method Reference \\
\hline $\begin{array}{l}909010163 \text { \#1 } \\
\text { 3-isobutyl-2-methoxypyrazine }\end{array}$ & $4.4 \mathrm{ng} / \mathrm{L}$ & 9/3/09 & \\
\hline $\begin{array}{l}909010164 \text { \#2 } \\
\text { 3-isobutyl-2-methoxypyrazine } \\
909010165 \# 3\end{array}$ & $4.3 \mathrm{ng} / \mathrm{L}$ & 9/3/09 & \\
\hline $\begin{array}{l}\text { 3-isobutyl-2-methoxypyrazine } \\
909010166 \# 4\end{array}$ & $6.2 \mathrm{ng} / \mathrm{L}$ & 9/3/09 & \\
\hline $\begin{array}{l}\text { 3-isobutyl-2-methoxypyrazine } \\
909010167 \text { \#5 }\end{array}$ & $7.0 \mathrm{ng} / \mathrm{L}$ & 9/3/09 & \\
\hline 3-isobutyl-2-methoxypyrazine & $5.1 \mathrm{ng} / \mathrm{L}$ & 9/3/09 & \\
\hline
\end{tabular}

The results in this report relate only to samples as submitted.

This report is intended only for the individual or entity to which it is addressed and may contain information that is privileged, confidential, and exempt from disclosure under applicable law. If the reader of this report is not the intended recipient or the person responsible for delivering this report to the intended recipient, you are hereby notified that any dissemination, distribution, or copying of this report is strictly prohibited. If you have received this report in error, please notify us immediately by telephone and return the original report to us at the address below via postal services.

This report shall not be reproduced except in full, without the written approval of ETS Laboratories.

Gordon Burns

Technical Director

Page 1 of 1

ETS Laboratories I 899 Adams St.I Suite A I St. Helena CA 94574 I Tel: 707.963.4806 I Fax: 707.963.1054 I info@etslabs.com I www.etslabs.com 


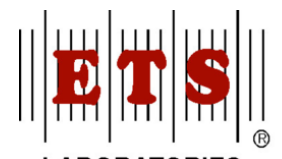

LABORATORIES

\section{REPORT LABORATORY \# 406230: 2009 MPs Sample Date 2}

Derby Wine Estates

Attn: Tiffinee Vierra

Post Office Box 5000

Paso Robles, CA 93447
Samples Received: 22 September 2009 10:00 am Analysis Reported: 23 September 2009 5:21 pm

\begin{tabular}{llll} 
Analyte & Result & Analysis Date & Method Reference \\
\hline 909220083 1 & & \\
3-isobutyl-2-methoxypyrazine & $<3.0 \mathrm{ng} / \mathrm{L}$ & $9 / 23 / 09$ \\
909220084 2 & & \\
3-isobutyl-2-methoxypyrazine & $<3.0 \mathrm{ng} / \mathrm{L}$ & $9 / 23 / 09$ \\
909220085 3 & & \\
3-isobutyl-2-methoxypyrazine & $<3.0 \mathrm{ng} / \mathrm{L}$ & $9 / 23 / 09$ \\
909220086 4 & & \\
3-isobutyl-2-methoxypyrazine & $<3.0 \mathrm{ng} / \mathrm{L}$ & $9 / 23 / 09$ \\
909220087 5 & & \\
3-isobutyl-2-methoxypyrazine & $<3.0 \mathrm{ng} / \mathrm{L}$ & $9 / 23 / 09$
\end{tabular}

The results in this report relate only to samples as submitted.

This report is intended only for the individual or entity to which it is addressed and may contain information that is privileged, confidential, and exempt from disclosure under applicable law. If the reader of this report is not the intended recipient or the person responsible for delivering this report to the intended recipient, you are hereby notified that any dissemination, distribution, or copying of this report is strictly prohibited. If you have received this report in error, please notify us immediately by telephone and return the original report to us at the address below via postal services.

This report shall not be reproduced except in full, without the written approval of ETS Laboratories.

Gordon Burns

Technical Director

Page 1 of 1

ETS Laboratories I 899 Adams St.I Suite A I St. Helena CA 94574 I Tel: 707.963.4806 I Fax: 707.963.1054 I info@etslabs.com I www.etslabs.com 


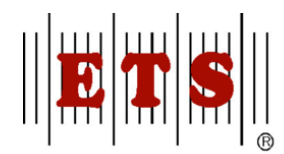

LABORATORIES

\section{REPORT LABORATORY \# 476985: 2010 MPs}

Derby Wine Estates

Attn: Tiffinee Vierra

Post Office Box 5000

Paso Robles, CA 93447
Samples Received: 7 December 2010 12:44 pm Analysis Reported: 17 December 2010 7:45 pm

\begin{tabular}{|c|c|c|c|}
\hline Analyte & Result & Analysis Date & Method Reference \\
\hline 0120703545211 & & & \\
\hline $\begin{array}{l}\text { 3-isobutyl-2-methoxypyrazine (berries) } \\
0120703555212\end{array}$ & $97.0 \mathrm{ng} / \mathrm{kg}$ & $12 / 17 / 10$ & \\
\hline $\begin{array}{l}\text { 3-isobutyl-2-methoxypyrazine (berries) } \\
0120703565213\end{array}$ & $115.2 \mathrm{ng} / \mathrm{kg}$ & $12 / 17 / 10$ & \\
\hline $\begin{array}{l}\text { 3-isobutyl-2-methoxypyrazine (berries) } \\
0120703575214\end{array}$ & $75.7 \mathrm{ng} / \mathrm{kg}$ & $12 / 17 / 10$ & \\
\hline $\begin{array}{l}\text { 3-isobutyl-2-methoxypyrazine (berries) } \\
0120703585215\end{array}$ & $85.8 \mathrm{ng} / \mathrm{kg}$ & $12 / 17 / 10$ & \\
\hline $\begin{array}{l}\text { 3-isobutyl-2-methoxypyrazine (berries) } \\
0120703595221\end{array}$ & $67.9 \mathrm{ng} / \mathrm{kg}$ & $12 / 17 / 10$ & \\
\hline $\begin{array}{l}\text { 3-isobutyl-2-methoxypyrazine (berries) } \\
0120703605222\end{array}$ & $34.6 \mathrm{ng} / \mathrm{kg}$ & $12 / 17 / 10$ & \\
\hline $\begin{array}{l}\text { 3-isobutyl-2-methoxypyrazine (berries) } \\
0120703615223\end{array}$ & $35.1 \mathrm{ng} / \mathrm{kg}$ & $12 / 17 / 10$ & \\
\hline $\begin{array}{l}\text { 3-isobutyl-2-methoxypyrazine (berries) } \\
0120703625224\end{array}$ & $29.1 \mathrm{ng} / \mathrm{kg}$ & $12 / 17 / 10$ & \\
\hline $\begin{array}{l}\text { 3-isobutyl-2-methoxypyrazine (berries) } \\
0120703635225\end{array}$ & $36.4 \mathrm{ng} / \mathrm{kg}$ & $12 / 17 / 10$ & \\
\hline $\begin{array}{l}\text { 3-isobutyl-2-methoxypyrazine (berries) } \\
0120703645311\end{array}$ & $42.9 \mathrm{ng} / \mathrm{kg}$ & $12 / 17 / 10$ & \\
\hline $\begin{array}{l}\text { 3-isobutyl-2-methoxypyrazine (berries) } \\
0120703655312\end{array}$ & $56.0 \mathrm{ng} / \mathrm{kg}$ & $12 / 17 / 10$ & \\
\hline $\begin{array}{l}\text { 3-isobutyl-2-methoxypyrazine (berries) } \\
0120703665313\end{array}$ & $60.2 \mathrm{ng} / \mathrm{kg}$ & $12 / 17 / 10$ & \\
\hline $\begin{array}{l}\text { 3-isobutyl-2-methoxypyrazine (berries) } \\
0120703675314\end{array}$ & $89.3 \mathrm{ng} / \mathrm{kg}$ & $12 / 17 / 10$ & \\
\hline $\begin{array}{l}\text { 3-isobutyl-2-methoxypyrazine (berries) } \\
0120703685315\end{array}$ & $70.7 \mathrm{ng} / \mathrm{kg}$ & $12 / 17 / 10$ & \\
\hline $\begin{array}{l}\text { 3-isobutyl-2-methoxypyrazine (berries) } \\
0120703695321\end{array}$ & $83.1 \mathrm{ng} / \mathrm{kg}$ & $12 / 17 / 10$ & \\
\hline $\begin{array}{l}\text { 3-isobutyl-2-methoxypyrazine (berries) } \\
0120703705322\end{array}$ & $20.4 \mathrm{ng} / \mathrm{kg}$ & $12 / 17 / 10$ & \\
\hline $\begin{array}{l}\text { 3-isobutyl-2-methoxypyrazine (berries) } \\
0120703715323\end{array}$ & $27.2 \mathrm{ng} / \mathrm{kg}$ & $12 / 17 / 10$ & \\
\hline $\begin{array}{l}\text { 3-isobutyl-2-methoxypyrazine (berries) } \\
0120703725324\end{array}$ & $29.2 \mathrm{ng} / \mathrm{kg}$ & $12 / 17 / 10$ & \\
\hline 3-isobutyl-2-methoxypyrazine (berries) & $41.4 \mathrm{ng} / \mathrm{kg}$ & $12 / 17 / 10$ & \\
\hline
\end{tabular}

Page 1 of 3

ETS Laboratories I 899 Adams St.I Suite A I St. Helena CA 94574 I Tel: 707.963.4806 I Fax: 707.963.1054 I info@etslabs.com I www.etslabs.com 


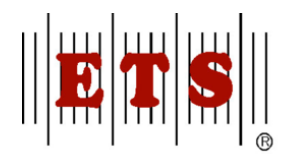

LABORATORIES

\begin{tabular}{|c|c|c|}
\hline \multicolumn{3}{|l|}{0120703735325} \\
\hline $\begin{array}{l}\text { 3-isobutyl-2-methoxypyrazine (berries) } \\
0120703745411\end{array}$ & $43.4 \mathrm{ng} / \mathrm{kg}$ & $12 / 17 / 10$ \\
\hline $\begin{array}{l}\text { 3-isobutyl-2-methoxypyrazine (berries) } \\
0120703755412\end{array}$ & $42.0 \mathrm{ng} / \mathrm{kg}$ & $12 / 17 / 10$ \\
\hline $\begin{array}{l}\text { 3-isobutyl-2-methoxypyrazine (berries) } \\
0120703765413\end{array}$ & $74.9 \mathrm{ng} / \mathrm{kg}$ & $12 / 17 / 10$ \\
\hline $\begin{array}{l}\text { 3-isobutyl-2-methoxypyrazine (berries) } \\
0120703775414\end{array}$ & $57.6 \mathrm{ng} / \mathrm{kg}$ & $12 / 17 / 10$ \\
\hline $\begin{array}{l}\text { 3-isobutyl-2-methoxypyrazine (berries) } \\
0120703785415\end{array}$ & $75.4 \mathrm{ng} / \mathrm{kg}$ & $12 / 17 / 10$ \\
\hline $\begin{array}{l}\text { 3-isobutyl-2-methoxypyrazine (berries) } \\
0120703795421\end{array}$ & $40.0 \mathrm{ng} / \mathrm{kg}$ & $12 / 17 / 10$ \\
\hline $\begin{array}{l}\text { 3-isobutyl-2-methoxypyrazine (berries) } \\
0120703805422\end{array}$ & $17.3 \mathrm{ng} / \mathrm{kg}$ & $12 / 17 / 10$ \\
\hline $\begin{array}{l}\text { 3-isobutyl-2-methoxypyrazine (berries) } \\
0120703815423\end{array}$ & $17.6 \mathrm{ng} / \mathrm{kg}$ & $12 / 17 / 10$ \\
\hline $\begin{array}{l}\text { 3-isobutyl-2-methoxypyrazine (berries) } \\
0120703825424\end{array}$ & $31.7 \mathrm{ng} / \mathrm{kg}$ & $12 / 17 / 10$ \\
\hline $\begin{array}{l}\text { 3-isobutyl-2-methoxypyrazine (berries) } \\
0120703835425\end{array}$ & $22.6 \mathrm{ng} / \mathrm{kg}$ & $12 / 17 / 10$ \\
\hline $\begin{array}{l}\text { 3-isobutyl-2-methoxypyrazine (berries) } \\
0120703845511\end{array}$ & $19.8 \mathrm{ng} / \mathrm{kg}$ & $12 / 17 / 10$ \\
\hline $\begin{array}{l}\text { 3-isobutyl-2-methoxypyrazine (berries) } \\
0120703855512\end{array}$ & $58.8 \mathrm{ng} / \mathrm{kg}$ & $12 / 17 / 10$ \\
\hline $\begin{array}{l}\text { 3-isobutyl-2-methoxypyrazine (berries) } \\
0120703865513\end{array}$ & $60.8 \mathrm{ng} / \mathrm{kg}$ & $12 / 17 / 10$ \\
\hline $\begin{array}{l}\text { 3-isobutyl-2-methoxypyrazine (berries) } \\
0120703875514\end{array}$ & $96.4 \mathrm{ng} / \mathrm{kg}$ & $12 / 17 / 10$ \\
\hline $\begin{array}{l}\text { 3-isobutyl-2-methoxypyrazine (berries) } \\
0120703885515\end{array}$ & $44.5 \mathrm{ng} / \mathrm{kg}$ & $12 / 17 / 10$ \\
\hline $\begin{array}{l}\text { 3-isobutyl-2-methoxypyrazine (berries) } \\
0120703895521\end{array}$ & $59.3 \mathrm{ng} / \mathrm{kg}$ & $12 / 17 / 10$ \\
\hline $\begin{array}{l}\text { 3-isobutyl-2-methoxypyrazine (berries) } \\
0120703905522\end{array}$ & $23.9 \mathrm{ng} / \mathrm{kg}$ & $12 / 17 / 10$ \\
\hline $\begin{array}{l}\text { 3-isobutyl-2-methoxypyrazine (berries) } \\
0120703915523\end{array}$ & $23.7 \mathrm{ng} / \mathrm{kg}$ & $12 / 17 / 10$ \\
\hline $\begin{array}{l}\text { 3-isobutyl-2-methoxypyrazine (berries) } \\
0120703925524\end{array}$ & $24.9 \mathrm{ng} / \mathrm{kg}$ & $12 / 17 / 10$ \\
\hline $\begin{array}{l}\text { 3-isobutyl-2-methoxypyrazine (berries) } \\
0120703935525\end{array}$ & $29.2 \mathrm{ng} / \mathrm{kg}$ & $12 / 17 / 10$ \\
\hline 3-isobutyl-2-methoxypyrazine (berries) & $31.0 \mathrm{ng} / \mathrm{kg}$ & $12 / 17 / 10$ \\
\hline
\end{tabular}

Page 2 of 3

ETS Laboratories I 899 Adams St.I Suite A I St. Helena CA 94574 I Tel: 707.963.4806 I Fax: 707.963 .1054 I info@etslabs.com I www.etslabs.com 


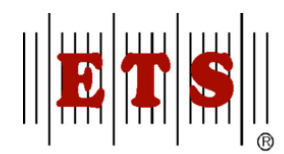

LABORATORIES

\begin{tabular}{|c|c|c|}
\hline \multicolumn{3}{|l|}{0120801865231} \\
\hline $\begin{array}{l}\text { 3-isobutyl-2-methoxypyrazine (berries) } \\
0120801875232\end{array}$ & $13.4 \mathrm{ng} / \mathrm{kg}$ & $12 / 17 / 10$ \\
\hline $\begin{array}{l}\text { 3-isobutyl-2-methoxypyrazine (berries) } \\
0120801885233\end{array}$ & $6.8 \mathrm{ng} / \mathrm{kg}$ & $12 / 17 / 10$ \\
\hline $\begin{array}{l}\text { 3-isobutyl-2-methoxypyrazine (berries) } \\
0120801895234\end{array}$ & 9.9 ng/kg & $12 / 17 / 10$ \\
\hline $\begin{array}{l}\text { 3-isobutyl-2-methoxypyrazine (berries) } \\
0120801905235\end{array}$ & $8.4 \mathrm{ng} / \mathrm{kg}$ & $12 / 17 / 10$ \\
\hline $\begin{array}{l}\text { 3-isobutyl-2-methoxypyrazine (berries) } \\
0120801915331\end{array}$ & $12.4 \mathrm{ng} / \mathrm{kg}$ & $12 / 17 / 10$ \\
\hline $\begin{array}{l}\text { 3-isobutyl-2-methoxypyrazine (berries) } \\
0120801925332\end{array}$ & $7.6 \mathrm{ng} / \mathrm{kg}$ & $12 / 17 / 10$ \\
\hline $\begin{array}{l}\text { 3-isobutyl-2-methoxypyrazine (berries) } \\
0120801935333\end{array}$ & $<5.0 \mathrm{ng} / \mathrm{kg}$ & $12 / 17 / 10$ \\
\hline $\begin{array}{l}\text { 3-isobutyl-2-methoxypyrazine (berries) } \\
0120801945334\end{array}$ & $14.5 \mathrm{ng} / \mathrm{kg}$ & $12 / 17 / 10$ \\
\hline $\begin{array}{l}\text { 3-isobutyl-2-methoxypyrazine (berries) } \\
0120801955335\end{array}$ & $10.5 \mathrm{ng} / \mathrm{kg}$ & $12 / 17 / 10$ \\
\hline $\begin{array}{l}\text { 3-isobutyl-2-methoxypyrazine (berries) } \\
0120801965431\end{array}$ & $13.5 \mathrm{ng} / \mathrm{kg}$ & $12 / 17 / 10$ \\
\hline $\begin{array}{l}\text { 3-isobutyl-2-methoxypyrazine (berries) } \\
0120801975432\end{array}$ & $8.3 \mathrm{ng} / \mathrm{kg}$ & $12 / 17 / 10$ \\
\hline $\begin{array}{l}\text { 3-isobutyl-2-methoxypyrazine (berries) } \\
0120801985433\end{array}$ & $5.6 \mathrm{ng} / \mathrm{kg}$ & $12 / 17 / 10$ \\
\hline $\begin{array}{l}\text { 3-isobutyl-2-methoxypyrazine (berries) } \\
0120801995434\end{array}$ & $7.3 \mathrm{ng} / \mathrm{kg}$ & $12 / 17 / 10$ \\
\hline $\begin{array}{l}\text { 3-isobutyl-2-methoxypyrazine (berries) } \\
0120802005435\end{array}$ & $8.1 \mathrm{ng} / \mathrm{kg}$ & $12 / 17 / 10$ \\
\hline 3-isobutyl-2-methoxypyrazine (berries) & $14.7 \mathrm{ng} / \mathrm{kg}$ & $12 / 17 / 10$ \\
\hline
\end{tabular}

The results in this report relate only to samples as submitted.

This report is intended only for the individual or entity to which it is addressed and may contain information that is privileged, confidential, and exempt from disclosure under applicable law. If the reader of this report is not the intended recipient or the person responsible for delivering this report to the intended recipient, you are hereby notified that any dissemination, distribution, or copying of this report is strictly prohibited. If you have received this report in error, please notify us immediately by telephone and return the original report to us at the address below via postal services. This report shall not be reproduced except in full, without the written approval of ETS Laboratories.

Gordon Burns

Technical Director

Page 3 of 3

ETS Laboratories I 899 Adams St.I Suite A I St. Helena CA 94574 I Tel: 707.963.4806 I Fax: 707.963.1054 I info@etslabs.com I www.etslabs.com 


\section{APPENDIX E}

Photographs by Thomas Fertel

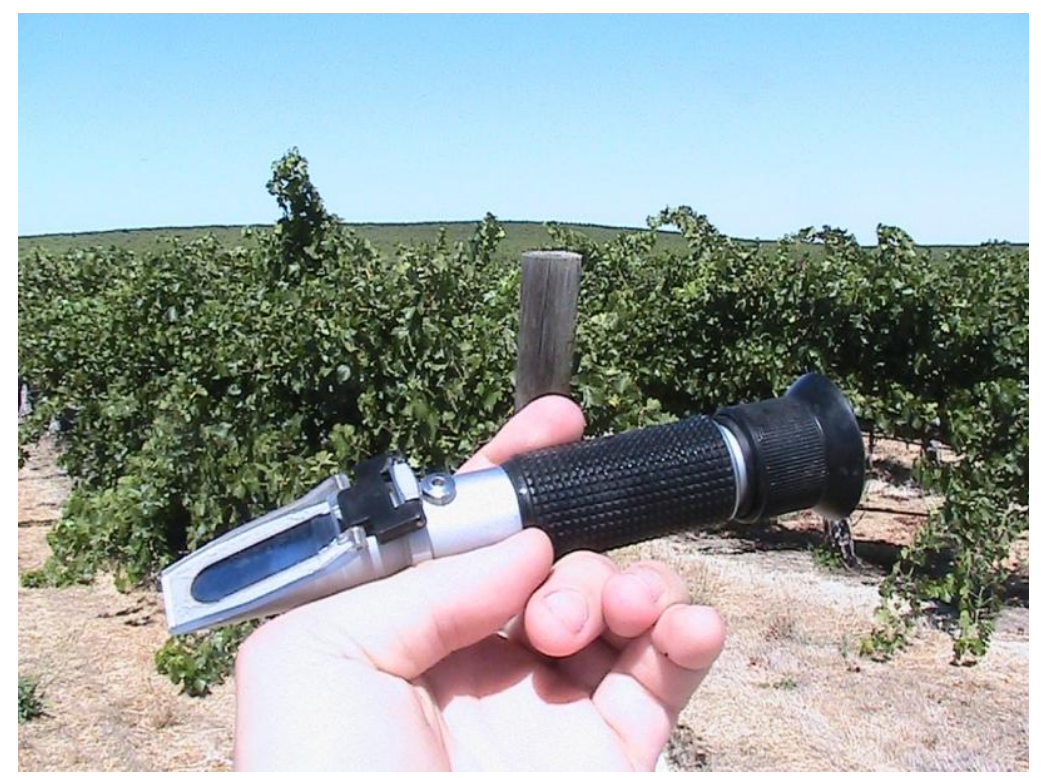

Fig. 8. Field refractometer used to measure soluble solids.

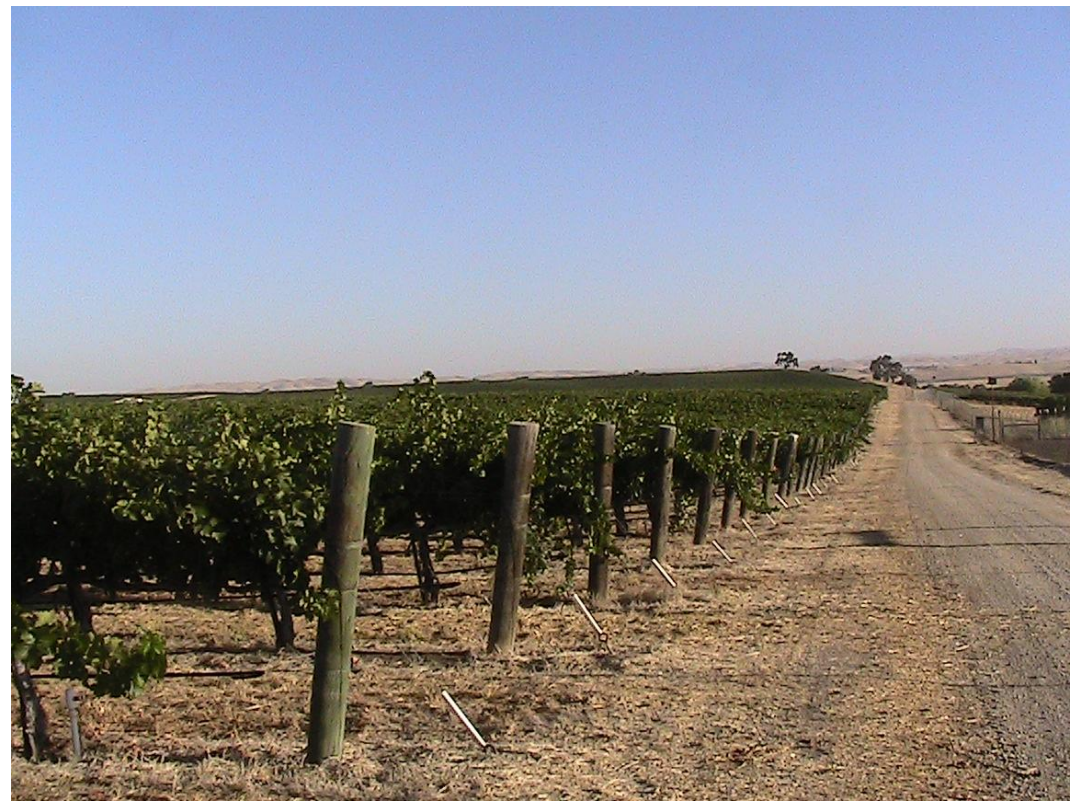

Fig. 9. Edge of Block 14 of Derby Wine Estates vineyard. 


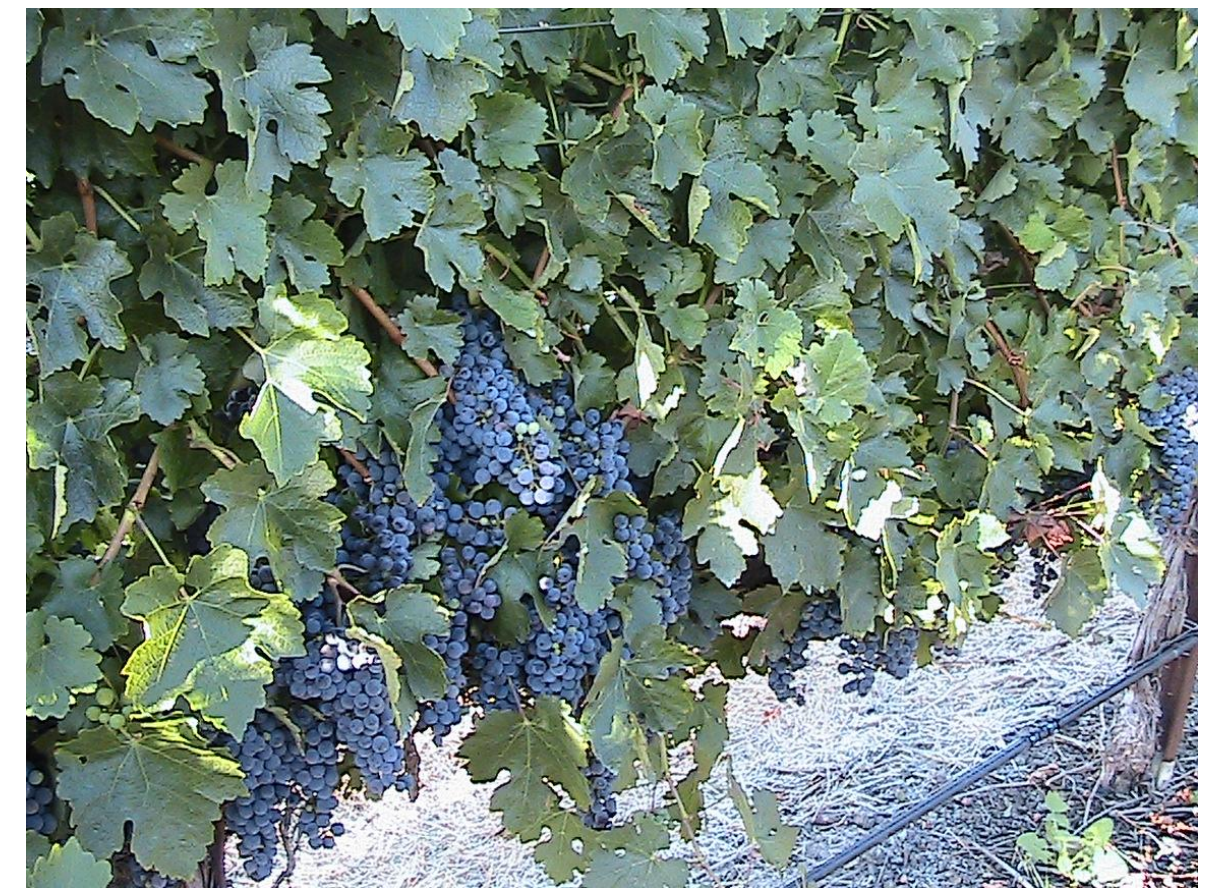

Fig. 10. Close up of the canopy in Block 14 of Derby Wine Estates vineyard.

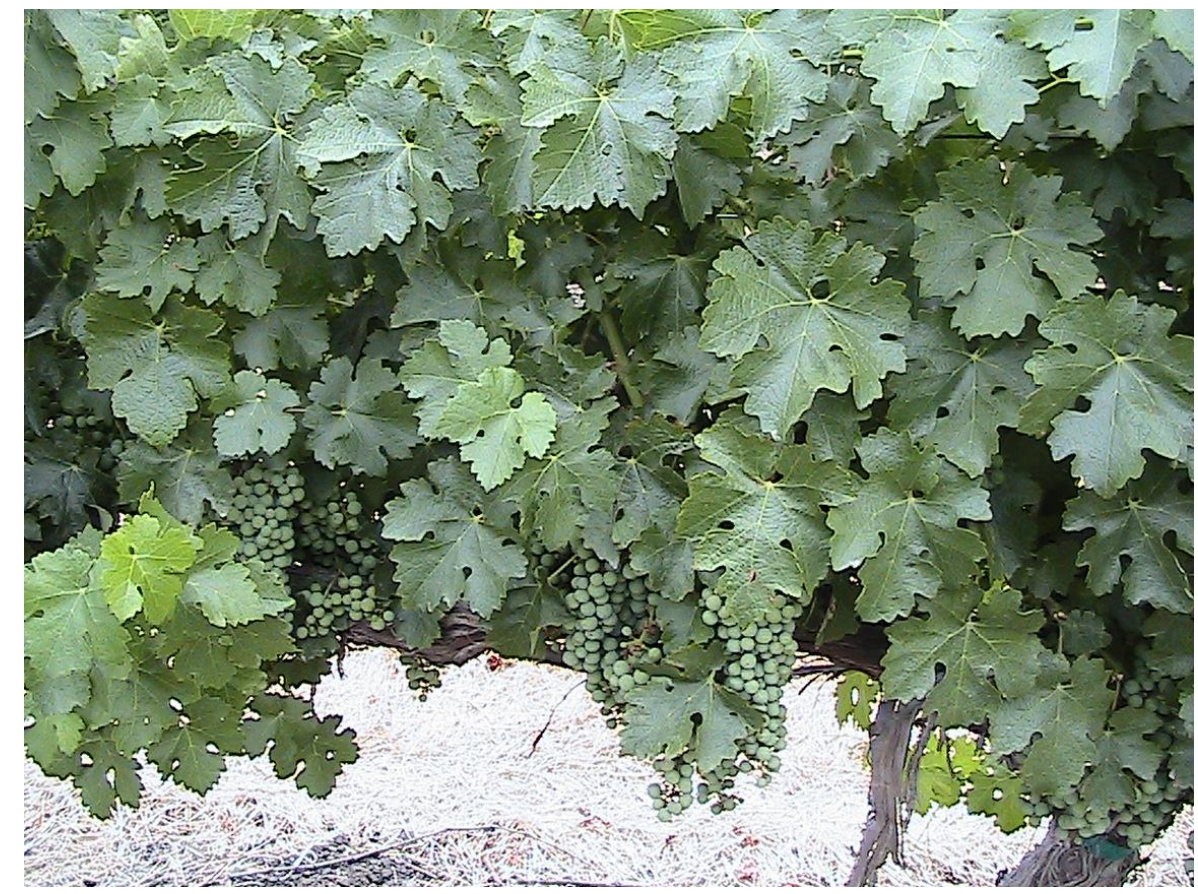

Fig. 11. Lag phase in Block 14 of Derby Wine Estates vineyard. 